\title{
1975: MUERTO FRANCO, ¿QUÉ DEBATES Y QUÉ HISTORIAS NOS PERMITIMOS CUESTIONAR?
}

\author{
1975: MORTO FRANCO, QUE DEBATES E QUE HISTÓRIAS NOS PERMITIMOS QUESTIONAR?
}

\author{
Adriana Minardi ${ }^{1}$
}

RESUMEN: Podríamos decir que, a partir de 1975, comienza en España un proceso de repatriación de la Historia que se impuso a través de tres olvidos: el de la República, el de la Guerra civil y el del Franquismo, pautado por la Transición democrática. Si entendemos que "toda narración, autobiográfica o novelesca, histórica o inventada depende de la memoria de alguien” (VERNON, 1989, p. 429), uno de los primeros actos en un relato es construir y representar una memoria ficticia e imitar el proceso rememorativo atendiendo a una concepción determinada de la memoria. Esta concepción depende de una estructura específica que conjuga una poética y una narrativa. En el siguiente artículo expondremos los debates acerca de las relaciones siempre conflictivas entre memoria, historia y política para luego proyectar el análisis a un texto autobiográfico.

Palabras clave: Memoria; historia; política; autobiografía.

RESUMO: Podemos dizer que, a partir de 1975, iniciou-se na Espanha um processo de repatriamento da história, imposto por três esquecimentos: o da República, o da Guerra Civil e o do franquismo, pautados pela transição democrática. Se entendermos que "toda narração, autobiográfica ou fictícia, histórica ou inventada depende da memória de alguém" (VERNON, 1989, p. 429), um dos primeiros atos de um relato é construir e representar uma memória fictícia e imitar o processo rememorativo atendendo a uma determinada concepção da memória. Essa concepção depende de uma estrutura específica que conjuga uma poética e uma narrativa. No artigo a seguir, exporemos os debates sobre as sempre conflitantes relações entre memória, história e política e projetaremos a análise a um texto autobiográfico.

Palavras-chave: Memória; história; política; autobiografia.

La memoria es el alma y el alma debe ser poco más que la memoria pues no existe un sólo acto psíquico del que la memoria pueda estar ausente

(BENET, J.,1965, p.37)

\section{Introducción}

Si toda Memoria histórica supone una Política de la memoria ${ }^{2}$, su corporización se ve

\footnotetext{
${ }^{1}$ Doctora en Letras por la Universidad de Buenos Aires-UBA, Argentina. Docente en las cátedras de Literatura Española III (Moderna y Contemporánea) de la Facultad de Filosofía y Letras de la Universidad de Buenos AiresUBA, Argentina.

${ }^{2}$ Como lo ilustra la polémica entre Eric Hackl (2001a, 2001b) y Antonio Muñoz Molina (2001) acerca del "hacer memoria" en torno de Sefarad y a propósito del testimonio y la historia.
} 
reflejada en un proyecto que, desde los años '80, busca recuperar un pasado republicano anulado. En un nivel descriptivo, las temáticas de estos relatos, ensayísticos en su mayoría, de la memoria, no se oponen a la historiografía emergente de esta época, como hemos ya analizado ${ }^{3}$, pues su misma configuración apunta a una crítica de la memoria oficial y de componente más nacionalista de la guerra civil y el totalitarismo franquista. Éstas buscan, por consiguiente, la integración del saber, sentir, actuar, colectivos (WINTER, 2006). Las creencias colectivas delinean una política de la memoria que deja de leer en la historia los relatos de los grandes hombres para buscar restos de la República en la microhistoria cotidiana y en el análisis de los procesos de larga duración. La inclusión del mundo histórico, así fuere bajo la forma de la ironía o de la crítica explícita, proyecta la idea de una rememoración que busca la totalidad y que entiende que la hegemonía presenta una contrahegemonía ${ }^{4}$. La historia estaría sumida en procesos de cambio constante lo que sería, a su vez, el indicio de un quiebre entre la memoria transmitida (Erfahrung) y la vivida (Erlebnis), a partir del declive moderno de la religión cristiana, dando paso a la construcción del concepto de "religión civil" por el que se producirían nuevas interpretaciones políticas y sociales de la memoria. ${ }^{5}$ En este sentido, los trabajos de J. Assman (1992) centran el problema en cómo se transforma la historia. Este punto es central para comprender también el desplazamiento de la memoria viva a la memoria cultural. Por lo que dicho proceso, en la narrativa de Juan Benet, tanto en la ensayística como en sus novelas, se focaliza en la superación del mito de las dos Españas, que lejos de ser ya una aporía existencial, se vuelve necesariamente, un dilema epistemológico. Recordar, hacer historia, hacer la historia, suponen axiomas prácticos que, lejos ya tamben del ámbito privado, asumen, incluso en tensión con la intimidad, la responsabilidad de la publicidad. Estas características, como señala E. Traverso (2000), suponen una dimensión política de la memoria colectiva, lo que afectaría las formas del hacer historia. Así, la búsqueda del pasado también ha hecho de la memoria, cuyo soporte privilegiado es el relato testimonial, el problema central de la novela histórica. La progresiva hibridación del género narrativo y, en especial, de la novela, hace imposible la separación entre historia y memoria y obliga a pensar que la Historia no pertenece ya a la esfera prototípicamente científica y pública, y la memoria a una individual o colectiva sino que la Memoria cultural, al ser esa búsqueda del pasado, se nutre indefectiblemente de la historiografía así como también de la literatura testimonial. Lo mismo que para la Historia (BENET, 1976, 1986), ocurre para la concepción de Memoria como puede verse en Épica, Noética, Poiética (BENET, 2003, pp. 9-46) respecto de la canción popular "La gallina ética", atribuida a Aristóteles.

Se diría que la imagen de la memoria traída a colación es de nuevo impresa cada vez que se recuerda, al tiempo que se destruye la imagen anterior como una copia inútil y carente de actualidad que no merece ser guardada en el reducido archivo de la mente. De forma que cada recuerdo es una nueva simplificación -y, cuando menos, alteración- de las imágenes de la memoria que poco a poco va convirtiendo a la estampa del objeto original en una de

\footnotetext{
${ }^{3}$ Ver: Minardi, A. "El sentido de práctica discursiva en Qué fue la guerra civil, de Juan Benet. La construcción del intelectual después de Franco", Espéculo, revista digital cuatrimestral de la UCM (Universidad Complutense de Madrid), Madrid, España, $n^{\circ}$ 32, marzo de 2006.

${ }^{4}$ Partimos de la perspectiva teórica, superadora de concepto de ideología por la que A. Gramsci entiende lo hegemónico a partir de su relación dialéctica con la contrahegemonía.

${ }^{5}$ La sacralización de la memoria no sólo la opone a la Historia sino que tiende a asimilarla al acontecimiento ya que el testimonio no reproduce una realidad fáctica fundadora sino que él mismo se constituye en tanto acontecimiento.
} 
tantas abstracciones con que el pensamiento se tiene que conformar para llevar a cabo con agilidad sus numerosas funciones: palabras, ideas, líneas, siluetas o colores. (2003, p.31)

La memoria, como parte de la Cultura, entonces, agrupa tanto al testimonio como al discurso histórico. Ambos se sitúan en el marco de la fenomenología, marco desde el cual K. Benson (1989) parte para caracterizar la narrativa benetiana. De esta forma, la referencia es una construcción subjetiva y la memoria juega un rol central por cuanto funciona como el pilar proyectual literario de Juan Benet que apunta al desmontaje de la tradición realista española, y a la construcción de un gran estilo perdido en la "Entrada en la taberna" (1965, p. 9). Esto explica que la estructura narrativa responda a una simbología, tanto histórica como testimonial, a partir de la metáfora del estado de ruina. El modo de "la estampa" propone esa estructura ligada a la rememoración que cifra todo el valor en la imagen (1965, p. 151), mientras que el modo del argumento "se cifra en la composición en interacción de unas líneas de convergencia [...] que carecen de razón si no hay un principio y un fin” (ibid.).

Esta forma de la temporalidad interna no cronológica trae consigo una concepción altamente espacial de la narrativa que funcionaliza la ruina como el espacio de la memoria utópica. Para superarla es necesaria la recuperación de la tradición literaria, entendida como la narrativa o el texto escribible ${ }^{7}$ que hace posible la conjunción de la Historia y la Memoria comunicativa como parte de una Memoria cultural a partir de los grandes temas del hombre. Estas temáticas recuperan, en especial, la memoria republicana y los valores reformistas; particularmente, aquellos de la tradición krausista y se materializan narrativamente en lugares específicos que ya no son solamente propios de la topografía sino también producto de una topología, dada por la memoria discursiva republicana. En este sentido, los lugares de memoria, según señala P. Nora (1997), abren el juego a ambas posibilidades, tanto a la deconstrucción ${ }^{8}$ de aquellas topografías en tanto topologías así como a la emergencia de aquéllas caídas frente a la hegemonía del nacionalismo católico y el proyecto innovador de la tecnocracia del Opus Dei en la última fase del franquismo. La memoria brinda una dimensión temporal así como una conciencia del pasado y, de esta manera, la obliga a enfrentarse con sus propias condiciones de existencia que son colectivas, en el sentido en que lo define M. Halbwachs (1968). Las memorias comunicativas de aquellos silencios que hemos mencionado, deben reconstruirse en la narrativa para entrar en el campo de la memoria colectiva que es la que se compone tanto de la memoria oficial, histórica, como de la comunicativa.

Si a la división que presenta Halbwachs entre historia y memoria, se le opone una síntesis con la noción de memoria cultural y colectiva, queda claro que es la narrativa la que

\footnotetext{
${ }^{6}$ También definido como "una zona de sombra, no sólo donde el conocimiento no ha entrado todavía, sino ante el cual se detiene y suspende toda actividad. Eso es el misterio" (1976b, p.50). Ver también la referencia a este concepto que retoma J, Margenot III (1991) en Zonas y sombras: aproximaciones a Región de Juan Benet.

${ }^{7}$ La narrativa, en tanto experimenta formas nuevas, tiene la función función de crear un texto escribible, en la terminología de Barthes. Para Benet sólo el texto escribible es el que realmente es literario, mientras que el legible se correspondería con el propio del realismo tradicional. De esta forma, el gran estilo es propio de "una literatura que no sintiéndose apremiada por la obligación de representar la naturaleza también progresivamente va eliminando de su código la necesidad de ser inequívoca, veraz y certera” (1976, p.48). La narrativa, entonces, los presenta para demostrar la insuficiencia gnoseológica y la insolubilidad de aquéllos; e incluso [...] de fomentar la invención de aquella clase de misterio que por su naturaleza se encuentra y se encontrará siempre más allá del poder del conocimiento (íbíd, pp.48-49).

${ }^{8}$ Muchos autores, como por ejemplo M. Valdéz (1989), proponen como concepto preferiblemente español el de desmontaje en oposición al derrideano.
} 
viene a subsanar ese hiato ${ }^{9}$ al intentar reestablecer la continuidad que la historia, en tanto sentido, tiene para la memoria. Si la historia presupone un saber científico acerca del pasado, la memoria comunicativa, según J. Assman, se crea de manera informal por el contacto directo entre las generaciones. La memoria cultural que es colectiva, comprendería tanto la historia como la memoria comunicativa y se correspondería con el saber común al cual recurre una comunidad, sociedad o nación para crear su identidad (ASSMAN, 1992). Se encargaría también de organizar e institucionalizar las formas de recordar el pasado porque este saber es, ante todo, pragmático. De esta manera, la historia contribuye a la memoria cultural, de la misma manera que la memoria comunicativa pero, en contraposición a la idea de una continuidad entre el testimonio o memoria comunicativa y la Historia, que oficiaría como su elemento configurador para la posteridad, la narrativa benetiana entiende que esta última, determinada por la Guerra civil española, viene a romper con la memoria comunicativa y a instalar imperativamente la memoria oficial, histórica, representada por el franquismo. El orden lógico/causal o cronológico del relato realista es un orden impuesto por el afán de sistematización de la razón. En la poética benetiana se propone, en cambio, la distorsión como modo de ruptura de este exceso determinista propio de la narrativa realista. Esta distorsión, propia de la construcción de una zona de sombras propone la libertad de una rememoración, no ligada al principio mimético sino al claroscuro propio de la estructuración de la memoria que será central en las novelas benetianas. La antítesis básica de un acontecimiento como la Guerra civil española, surge por la oposición entre experiencia colectiva y experiencia individual. La primera se corresponde con la idea de la Prehistoria republicana, también vista, con reservas, como el universo de la memoria semiótica; la segunda, en cambio, con la Historia, ligada a la memoria simbólica ${ }^{10}$. Como hemos señalado, ambas se corresponden con la noción de Memoria cultural que las reúne como resultante de la clave narrativa.

La memoria posee, sin lugar a dudas, un estatuto matricial. De este estatuto prevalece como fundamento interior, el proceso de presentificación (Vergegenwärtigung) que polariza los acontecimientos en historia anterior y posterior y singulariza la historia; la Historia (que no es ciencia porque en sí misma es una forma de recuerdo por el archivo), mediante la flexión metanarrativa, reifica la memoria (RICOEUR, 2000; HUTTON, 1993) pero es la primera la que le otorga su cualidad final: el sustrato subjetivo a partir de las dos dimensiones complementarias, según señalara F. Hegel, de historia rerum gestarum y res gestae. Narración y acontecimiento se conjugan en la necesaria aparición de la Ley estatal que los organiza, los jerarquiza en relatos, basados en la heroicidad o en el rescate de la microhistoria, y les da una entidad, mediante la función conmemorativa, de loci de memoria. El estatuto matricial de la memoria en relación con la Historia estaría en el eje de la narración como organización necesaria y determinante de lo temporal.

1.1 Lieux de mèmoire: tópica y topografía del pasado

Los lugares de la memoria han sido definidos desde la óptica de aquellos artefactos, concretos y simbólicos, que un Estado utiliza para afianzar su posición hegemónica. P. Nora

\footnotetext{
9 "If a memory exists only when the remembering subject, individual or group, feels that it goes back to its remembrances in a continuous movement, how could history ever be a memory, since there is a break in continuity between the society reading this history and the group in the past who acted in or witnessed these events (HALBWACHS, 1968, p. 79)

${ }^{10}$ La distinción que, partiendo de J. Lacan, utiliza J. Kristeva se basa en la diferente función, dialéctica, entre una memoria simbólica de la realidad y una semiótica de la misma.
} 
(1997) vuelve sobre el problema de la aceleración de la historia, la oposición Historia/Memoria y el argumento de la continuidad para analizar los relatos de los lugares de memoria, relatos sordos que guardan relación tanto con la memoria histórica como con la colectiva. En este sentido, Nora entiende que la memoria es una consecuencia simbólica de los marcos sociales; por esto mismo, reviste carácter sagrado y cambiante, mientras que la historia es la representación del pasado y la distancia respecto del presente. Lugares, topoi de memoria supone ver, en nuestro caso, esas variaciones de la España monopolista y uniforme que recupera distintas memorias del republicanismo. Explica P. Nora que analizará

[...] no los acontecimientos por sí mismos sino su construcción en el tiempo, el apagamiento y la resurgencia de sus significados, no el pasado tal como tuvo lugar sino sus reempleos permanentes, sus usos y desusos, su pregnancia sobre los presentes sucesivos; no la tradición sino la manera en que se constituyó y transmitió. En síntesis, ni resurrección ni reconstrucción, ni aun representación; una rememoración. Memoria: no el recuerdo sino la economía y administración del pasado en el presente. Una historia de Francia, por lo tanto, pero en segundo grado. (NORA, 1997, p.4)

La intención de P. Nora suponía la realización de un inventario. Dicho inventario dejó aún más a la deriva la noción de lugar de memoria puesto que no sabemos si entender el topos concreto o el uso simbólico. Así, por ejemplo, Le Grand Robert de la langue française define en 1993 el lieu de mémoire como "una unidad significativa, de orden material o ideal, a la que la voluntad de los hombres o el trabajo del tiempo convirtieron en un elemento simbólico de una determinada comunidad" ${ }^{\prime 1}$.

En este sentido, la literatura testimonial y la historiografía españolas, así como la novela histórica, han preferido distinguir entre lugares de memoria y depósitos de memoria, reservando el primero para las categorías prefijadas por P. Nora, y dejando al último un empleo más libre y difuso (CUESTA BUSTILLO, 1998, p. 219), donde hasta un nombre propio es entendido como un lugar de memoria. En los últimos años, y dado el mayor alcance del memorialismo en España, con un fuerte impulso en la novela y el ensayo desde la muerte de F. Franco en 1975, se le suma a la recuperación del pasado actividades de museización e, incluso, de búsqueda, como es el caso de la fosa de F. G. Lorca. Numerosos estudios críticos han realizado las aportaciones para esta noción ${ }^{12}$ en el caso español. La desaparición de las sociétés-mémoires (1984, 1 , p. 23) produce a su vez un quiebre entre el pasado y el presente, donde la memoria viva, también perdida, es recuperada por el puente de los lieux de mémoire que se manifiestan como la mediación de esa distancia o presencia-ausencia. Como fenómeno de las sociedades modernas,

\footnotetext{
${ }^{11}$ En ambos casos, la influencia de lo colectivo es central por cuanto se comprende que un lugar de memoria es una construcción social y, ante todo, política.

${ }^{12}$ Sólo a título ilustrativo, podría hacerse una rápida referencia al ámbito del hispanismo alemán: la celebración en 2003, en el marco del XIV Congreso de la Asociación de Hispanistas Alemanes, de la sección de conferencias "Lugares de memoria e identidades colectivas en la España democrática"; la publicación, en 2004, de los dossiers de Iberoamericana "Postdictadura/postmodernismo: La renegociación de identidades colectivas en la España democrática: entre memoria histórica, cultura popular y cultura política" (ULRICH, 2004) y "Memoria y transición española: historia, literatura, sociedad” (LÓPEZ DE ABIADA, 2004); y de los volúmenes Casa encantada. Lugares de memoria e identidades culturales en la posmodernidad ibérica (RESINA Y WINTER, 2005) y Lugares de memoria de la Guerra Civil y el franquismo. Representaciones literarias y visuales (2006), junto a los estudios de J. F Colmeiro (2005) (Memoria histórica e identidad cultural. De la Postguerra a la Postmodernidad).
} 
la irrupción del presente en el que ese pasado cobra vigencia es lo central. Es por eso, que nos interesa más su dimensión simbólica para el caso de la literatura española a partir de la muerte de Franco. En el breve ensayo de 1984, "Entre Mémoire et Histoire”, Nora se encarga de precisar que los lieux lo son simultáneamente en tres sentidos: material, simbólico y funcional. El primero los fijaría en realidades dadas y manejables; el segundo sería obra de la imaginación, garantizaría la cristalización y transmisión de los recuerdos; y el tercero sería el que conduce al ritual.

Ya desde el primer volumen, P. Nora destaca la función de la literatura que, cual lieux de mémoire, en tanto signos que remiten a sí mismos, están necesariamente vinculados a la metáfora del espejo, esa mémoire-miroir, autoreferencial, metaliteraria. La disyuntiva literatura-memoriahistoria se resolvería con la propuesta de esta noción y la narrativa testimonial, en especial, junto a la novela histórica, los pilares de la rememoración colectiva, aunque no sólo de la memoria imperante sino de aquella otra memoria contrahegemónica.

No se trata, entonces, de resolver la noción en simples emplazamientos topográficos dados a la conmemoración sino, quizás, y retomando a J. Courtine (1981), de aquellas variaciones de la memoria discursiva, en tanto construcción social. Los lieux de mémoire, en tanto noción resultan operativos para el abordaje de los modos en los que la literatura española contemporánea reconstruye el pasado reciente, a saber: volverla consciente de la posibilidad de ser ella misma partícipe de un proceso similar al que analiza.

En tanto elementos del poder, no obstante, estos lugares también se ven resemantizados en una memoria colectiva cuyo capital se ha ido construyendo sobre la base de rituales, tradiciones y elementos opuestos a la memoria histórica oficial. Para M. Halbwachs, la forma en que los individuos construyen su subjetividad es necesariamente a partir de marcos sociales. Oponiéndose a H. Bergson, este planteo supone un código compartido (he aquí cómo la lengua resulta esencial), un cuadro social, donde la familia opera como pivote principal y determinadas coordenadas sociales que conforman la memoria individual sólo en los límites de la memoria colectiva. Estos cuadros sociales cumplen la función de conceptualizar y espacializar la memoria. En el caso español, la crisis de la memoria histórica no fue en detrimento de la memoria colectiva. La legislación del olvido de la memoria colectiva de la Guerra civil española y del franquismo en la inmediata Postguerra, seguida del pacto de la transición en la democracia han generado una amnistía sustentada por la amnesia, donde no pocas narrativas la han socavado. Aquí la noción de testigo es clave.

Desde el testigo integral, quien es aquel que ha sobrevivido, según P. Levi, al abismo y no puede relatar, a la figura del "musulmán", del portavoz, aquel que cree poder traducir el cuerpo, el lugar mismo de la memoria, en relato. Dice P. Levi: "Nosotros, hablamos en su lugar, por delegación” (1997, p. 73). Para G. Agamben (1998) el musulmán se vuelve el paradigma mismo de los campos de concentración puesto que demuestra la imposibilidad de la testificación; su carácter de frontera entre la vida y la muerte daría cuenta de la presencia de la ausencia, un ejercicio de memoria traducida pero, en última instancia, también un elemento de memoria colectiva.

Para el caso de la guerra civil, las visiones del musulmán operan como memorias discursivas que traen in praesentia elementos vedados por la legalidad franquista. Como topoi del no derecho, el testimonio en la narrativa benetiana busca resemantizar a partir de los ochenta (que es cuando empieza a darse un fuerte debate sobre la memoria de la Guerra civil española) lugares como Madrid, bastión de la resistencia republicana y figuras como Baroja que podrían entrar en una memoria histórica, a la vez que el recuerdo, y el correlativo relato, de los 
olores, las imágenes del encierro que ofrecía la España de Franco a la memoria de los testigos; es decir, a la memoria del testigo integral del período franquista y a la del musulmán, respecto de la Guerra civil española. Como señala J. Goytisolo en Cogitus interruptus (1999), memoria y olvido resultan complementarios puesto que la memoria necesariamente selecciona, desdibuja o intercala en omisiones y representaciones elípticas. El recuerdo no es fidedigno y es una configuración dada políticamente porque, en esencia, es social. Aquí se presenta también lo que Goytisolo llama memoricidio ${ }^{13}$.

A continuación, analizaremos cómo estas relaciones memoria/olvido se traman en el proyecto narrativo benetiano con el objeto de interpretar las representaciones del período franquista en torno de la guerra civil y de las memorias discursivas en juego.

\subsubsection{Memoria individual/ memoria colectiva, Historia/Memoria en el proyecto benetiano}

La literatura es un campo privilegiado para la transmisión de ciertos conocimientos, en especial, acerca del pasado, esa casa ajena y extraña como la define G. Bachelard (1998) ${ }^{14}$. En este sentido, como hemos mencionado, memoria e historia son el producto de una memoria colectiva, cultural y discursiva. Si a la división que presenta Halbwachs entre historia y memoria, se le opone una síntesis con la noción de memoria cultural y colectiva, queda claro que es la narrativa la que viene a subsanar ese hiato ${ }^{15}$ al intentar reestablecer la continuidad que la historia, en tanto sentido, tiene para la memoria. Como señala J. Colmeiro (2005) la crisis se encuentra en la memoria histórica, no en la relación entre historia y memoria. De esta manera, la narrativa testimonial y la novela y ensayo históricos constituyen el soporte para la resemantización de la memoria histórica contrahegemónica a partir de la reestructuración de sus lugares de memoria.

Ahora bien, todo lugar de memoria, incluso el simbólico, a nivel de depósito memorial, como la literatura testimonial, reviste carácter político por cuanto la pluralidad y la ausencia de relaciones de dominio son imprescindibles para la transmisión del testimonio. La figura del storyteller trata de unir comprensión histórica con imaginación, o memoria discursiva en este caso; es decir, tramar historia y memoria en un relato. Esta interpretación, dada por la mediación del testimonio, da al carácter ficticio un sentido de colectividad, de memoria imaginativa, donde el pasado funda, a partir del relato, una tradición. Quien narra su propia experiencia tiene las limitaciones propias del testigo: el punto de vista, por eso es esencial el espacio público en el que las distintas narraciones individuales pueden sopesarse y obtener el reconocimiento, no se trata en este caso de la legitimidad del recuerdo del individuo, sino de la legitimidad que el grupo le asigna a la narración al reconocerla como verdadera e integrarla al corpus de lo transmisible La verdad, de esta manera, es recreada y, luego, legitimada. Por un

\footnotetext{
${ }^{13}$ [...] La devastación programada de monumentos y edificios a fin de crear espacios vacuos sobre los que erigir otra historia, como ocurre en los territorios ocupados de Palestina, sería incompleta sin la supresión de la memoria escrita: el saber acumulado por sedimentación en las bibliotecas (1999, p.50)

${ }^{14} \mathrm{El}$ pasado que es la memoria definida temporalmente debería ser, justamente, por definición, la casa, el nido, el locus amoenus que brinda identidad. Cuando dicha temporalidad se quiebra o se exilia, la inmensidad íntima debe rememorar, mediante la ficción, dichos lugares y recuperar de la extranjería y aun del anonimato la memoria del pasado.

15 "If a memory exists only when the remembering subject, individual or group, feels that it goes back to its remembrances in a continuous movement, how could history ever be a memory, since there is a break in continuity between the society reading this history and the group in the past who acted in or witnessed these events (HALBWACHS, 1968, p. 79)
} 
lado, las narraciones del nacionalismo católico triunfante, del franquismo imperante frente a la memoria del republicanismo, con una Política de la memoria, basada en los Reyes católicos y en la figura heroica de Primo de Rivera. Por otro, la clandestinidad, no pública, invisible, de los relatos de la memoria reciente de la Guerra civil española y del franquismo. Las narraciones tienen sus héroes y sus moralejas. De ellas se desprende una evaluación ética que ancla en el presente y propone, como hemos visto, una resignificación del pasado, junto con deberes para el presente y el futuro. Por esto la tentación de controlar el pasado no suele ser resistida por gobiernos totalitarios, este intento de control se manifiesta en la invención de tradiciones, la incorporación de antiguos rebeldes populares a la historia oficial y cierta manía por los monumentos y gestos de reivindicación. Se construyen fábulas, como la que rodea a F. Franco ${ }^{16}$ y, de estas fábulas, se nutre la educación de los ciudadanos por lo que la perpetuación del poder está directamente relacionada con el control de estas narraciones. La crisis de la memoria genera, antes que un acuerdo, disidencias notables respecto de qué se debe recordar, cómo, si se debe recordar, si se debe olvidar, etc. ${ }^{17}$ La memoria colectiva, en tanto capital social, actúa en un nivel simbólico en el conjunto de las tradiciones, rituales y mitos de miembros pertenecientes a un grupo social. Lo social, de esta manera, como veíamos en Halbwachs, conceptualiza y espacializa la memoria. Tres tiempos marcarían este proceso de la memoria: el del franquismo, con sus tres momentos autárquico, desarrollista y, por último, el de la vía monárquico-institucional, todos ellos marcados por la representación épica del pasado glorioso de la España imperial. Es el tiempo de silencio, de L. M. Santos o el reinado de la elipsis, como lo llama M. Vázquez Montalbán en su Crónica (1986); el tiempo de la transición a la democracia entre la memoria del testimonio residual y la amnesia. El franquismo, tanto como la GC, se vuelven temas tabú; por último, el tiempo de la inflación cuantitativa y devaluación cualitativa de la memoria histórica; memorias dialectales motivadas por los nacionalismos que desencadenan una crisis de la memoria, dada por las caras de una misma moneda: amnistía y amnesia. El archivo juega un papel esencial, en tanto es también un lugar de memoria. Mientras la nostalgia es el núcleo semántico de la mayoría de los discursos franquistas, junto con el afán épico imperial ${ }^{18}$, el regreso será el de la memoria discursiva republicana. La imagen del pasado a partir del tópico del paraíso perdido hace que el regreso sea percibido como una infidelidad, como una traición al origen. Jo Labanyi (2000) caracteriza a la República como ese espacio ajeno al que se intenta volver, ya sea como mito, como vivencia de la niñez o como mera utopía. El regreso que conjuga todo el campo de la traición, también, como señala J. Benet: "Si el regreso es la mayor infidelidad, también es la mayor perseverancia" (2007, p.9). El regreso, entonces, supone también la doble condición del exilio externo, en su sentido más explícito, pero también del interno. Una de las constantes culturales durante el franquismo fue la condición del exiliado interior que, según P. Ilie (1980), se caracteriza por el sentimiento de una profunda alineación frente a la realidad adversa y represora. La reconstrucción del pasado individual y colectivo cumple la función de devolverles a los sujetos la identidad e historicidad negadas junto con la denuncia y condena, es un

\footnotetext{
${ }^{16}$ Nos referimos a la construcción personalista del propio líder, como en la película Raza o también los gestos épicos de Alba de América, Los últimos de Filipinas- aquí, con una interesante reformulación de los valores referidos al krausismo, al pesimismo crítico, el regeneracionismo y el anticlericalismo, junto con la revalorización de Numancia y Sagunto, Harka y Sin novedad en el Alcázar.

${ }^{17}$ Ramoneda y Vázquez Montalbán, entre otros, señalan la necesidad de una recuperación de la memoria histórica; Algunos intelectuales han comenzado a hablar de una "inflación de memorias" desde un punto de vista negativo, como Miret Magdalena, mientras otros hacen del olvido una ley catártica. Ver: Memoria y olvido de la guerra civil (2006) de Paloma Aguilar Fernández, La memoria insumisa. Sobre la dictadura de Franco. (1999) de Nicolás Sartorius y Javier Alfaya, Exorcismos de la memoria. Políticas y Poéticas de la melancolía en la España de la Transición (2001) de Alberto Medina Rodríguez.

${ }^{18}$ Sirva de ejemplo el "Canto a la España deseada" de Manuel Machado.
} 
ejercicio de producción de significados, de resemantización de la propia tradición. A partir de la nueva Constitución de 1978, se produce una realineación de la memoria y la identidad cultural en diversos lugares que configura un nuevo mapa de recuperación que apunta tanto a la reelaboración ficticia como documental. Con la transición, se produce la europeización y el proyecto del socialismo hace que la memoria histórica sea clave para reconstruir los conceptos de identidad, nación y memoria compartida. Evocar el pasado no sólo consiste en brindar información sino en construir sentidos. En Infidelidad del regreso (2007), Benet vuelve a retomar el núcleo problemático de la relación memoria/literatura a partir de lo que él denomina los modos narrativos de la onda y el corpúsculo. En el ensayo que oficia de prólogo, se focaliza en el núcleo semántico del regreso. Como señala D. Herzberger (1976), las denominadas "novelas de la memoria" de finales del franquismo y de los ` 80 , se enfrentan a la historia oficial presentada por el Régimen a la vez que se alejan del realismo social, buscando la rememoración en la transformación del pasado en relación dialéctica con el sujeto rememorador. Este es el pilar del proyecto novelístico y ensayístico de la obra de J. Benet. Con los conceptos de onda y corpúsculo, nos referimos a los modos de plasmar la memoria en una estructura literaria. La onda, el argumento y el corpúsculo, la estampa. No hay narrativa posible sin que ésta esté enmarcada en la memoria colectiva.

Pero, además, el alma deforma lo que la naturaleza conserva pues la memoria conserva la estampa a fuerza de adaptarla en todo instante a los requerimientos de cada día y los recuerdos arqueológicos- sacados a la luz por un golpe de fortuna, tras un largo período de ocultación- son los que mejor denuncian la permanente mutación de los archivos. (BENET, 2007, p. 8)

Ahora bien, si "la estampa" constituye fundamentalmente una modalidad narrativa centrada en el espacio, la memoria no puede entenderse sin una concepción del tiempo. El tiempo experimentado del que habla Ricoeur (1985) en el último tomo de su obra es la base de toda concepción de la memoria. Otro de sus ensayos lleva por título "Clepsidra", y contiene muchos rasgos lúdicos que marcan el tono irónico. El elemento clave es la figura del reloj de arena. Se parte de la concepción del tiempo que, de acuerdo con la enseñanza que hace "la física de todas las cosas del universo" (1985, p.104), estaría constituido por un ente finito son su "origen" y su "meta". Ello le lleva a discurrir sobre el tiempo anterior al tiempo y el origen de la nada y el caos primigenio. Linealidad frente a simultaneidad, momento o $\mathrm{TO}^{19}$ en el que la arena se mueve por la Clepsidra; ello lleva a reflexionar sobre la memoria y la conciencia pues distingue el momento estático de la clepsidra y el momento dinámico que es cuando la arena comienza a fluir. "El Caos no sería más que una montonera de instantes verbales sin orden ni concierto; que el tiempo comenzó con la organización del lenguaje” (1985, p.107).

Con la metáfora de la Clepsidra se opone el tiempo lineal a una simultaneidad mucho mayor. De la misma manera, la estampa es una porción del argumento. La Clepsidra pasa la mayor parte del tiempo en el caos (el montón de arena que se asienta en uno de sus extremos) y depende de que alguien le dé la vuelta para pasar a ser, infinitesimalmente, un tiempo lineal en movimiento. Esta es la concepción del tiempo subjetivo, del tiempo de la conciencia que va a caracterizar también la experiencia del tiempo y el espacio en la narrativa benetiana: la quietud caótica es la primordial frente a la linealidad organizada. La quietud caótica de la arena antes y después de ser emplazada hacia la linealidad corresponde al modo narrativo de la 'estampa',

\footnotetext{
${ }^{19}$ Tiempo cero del relato.
} 
mientras que la linealidad corresponde con el modo del 'argumento' de la escuela realista. Esta visión fenomenológica supone ver en el realismo un corte convencional en el flujo temporal (la linealidad de la Clepsidra depende de la convención de que se le dé la vuelta al artefacto), el estado natural del tiempo es el caos, anterior y posterior a esta linealidad. El gesto humano es el que organiza. Las narraciones de Benet suelen estar situadas en un espacio (Región) y emplazados en un tiempo histórico determinado (la guerra civil española y la Postguerra posterior, esto es, desde 1936 hasta 1960 aproximadamente). También se relaciona el modo estilístico por el que la metáfora, propia de la estampa, no se opone a la mimesis realista, el argumento. Esta zona se ubica en el límite de lo simbólico y lo semiótico, respectivamente. Dos argumentos, explicitados en el ensayo "Sobre el carácter tétrico de la historia", uno de los ensayos centrales de Juan Benet, publicado en Puerta de tierra (2003), funcionan como afirmación de la recuperación de la memoria: el primero remarca el rol institucional en necesaria concordancia con un sostén de utilidad que lo enmarca para la función de fortalecimiento de la identidad. Aquí la lección conmemorativa tiene su asiento en la importancia de la Educación:

[...] Pero lo que no vale es enseñar la Historia con un determinado carácter, sea nacionalista, religioso o cultural. Así que en cierto modo, la Historia la ciencia de la veracidad es el supremo esfuerzo intelectual del hombre porque es aquel que tiene que hacer en pugna con su condición. Esa suprema parcialidad de la Historia la ciencia de la sinécdoque, de la parcialidad o de lo incompleto está abiertamente reñida con el carácter compulsorio de su enseñanza y es por lo que decía que la Historia al menos esa clase de Historia es lo último a tener en cuenta, sí en cambio, una filosofía de la Historia. (p. 144)

En este sentido, "hacer memoria" supone ese ritual del entierro que analizaremos a partir de E. Runia, que nos lleva a construir el pasado a partir de las representaciones narrativas. En "Un ex tempore" (2003, p. 71), a propósito de la muerte de su hermano ${ }^{20}$, la conciencia temporal reposa sobre la rememoración, sobre la memoria como un continuum, alejado de lo contable del tiempo. La imagen que elige es la del teletipo que, aún no emitiendo imágenes, se encuentra trabajando, así, nuestra idea del tiempo se resume en prácticas y no en una conciencia del tiempo. Por eso no es cuantitativo ni mucho menos cualitativo, "no se diferencia tampoco dentro de su seno de ninguna de sus posibilidades sino cuando se convierte en existencia, cuando se consume" (p.74). El pasado, en ese sentido, no sería tiempo puesto que es el hombre el que lo transforma en existencia convirtiendo lo no cuantitativo en un cualitativo cuyo depositario es la memoria. El presente tampoco es tiempo puesto que adquiere el estatuto temporal por la experiencia cualitativa de la memoria.

El presente puede así pertenecer a una de las dos familias: lo recordado o lo nuevo; el que viene a acumularse en el espectro conocido o el que viene a ampliarlo. Sólo el segundo es verdadero tiempo en el sentido que sólo él, con el acontecer, se puede transformar en existencia. El primero ya lo era- una preexistencia tan sólo pendiente de la precipitación cronológica- carente por

\footnotetext{
${ }^{20}$ Vale recordar las implicancias ideológicas que sobrevuelan este texto- a partir de la sombra de la guerra- ya que Francisco desapareció en un accidente en abril de 1966 y muerto en el exilio, tras organizar la fuga de Cuelgamuros en 1948 .
} 
su carácter de toda posible transformación y desposeído de su esencial posibilidad. (p.75)

La memoria devora a la existencia; no recuerda sino que reproduce, mediando el olvido, las representaciones donde lo nuevo viene a configurar el archivo. Por eso el olvido y la imaginación son partes esenciales de la transformación del tiempo en existencia, es decir, de la memoria. La historia, como esa disciplina que viene a sustentar determinada visión del pasado, a diferencia del interés personal, privado del testimonio, cumple una función pública. La historia, en el sentido que le asigna Benet, tiene, luego, una utilidad.

Una Filosofía de la historia reclama reflexión y nuevas representaciones del pasado que logren, además, influir en el presente. Y es la construcción del ethos del intelectual, a partir de dichas representaciones, donde tiene la función de moralizar para advertir acerca de los errores del pasado; debe, también, dar cuenta de cómo ha devenido eso que se da en llamar, en nuestro análisis, por ejemplo, España y memoria discursiva republicana ${ }^{21}$. Y, por último, debe legitimar -y es aquí donde entra en juego la aplicación necesaria de la representación o razón imaginativa a través de la ideología- el estado democrático en detrimento de los nacionalismos fascistas. En este momento entran en juego las luchas por el poder de la representación y de las versiones interpretativas que más se ajustan al sentido histórico que haga justicia al pasado elidido. En otro artículo, titulado "La novela en la España de 1980" (2007, p.131), las tesis presentadas arremeten nuevamente contra el realismo social, como producto del Régimen en oposición al resurgimiento de una novela, en 1980, capaz de estar a la altura de la Democracia, no sin entrar en debate.

[...] ¿estamos viviendo acaso nuestra definitiva inclusión dentro del sistema democrático?, ¿o la etapa actual de libertades y derechos civiles no será la postre sino una breve estancia en aquel sistema que, para nuestra desgracia, se verá contradicha y destruida por un nuevo paso atrás hacia cualquier forma moderna de opresión? Pues así ha sido nuestra historia moderna: por cada cinco años de liberalismo y democracia nos vemos obligados a pagar con medio siglo de absolutismo o dictadura. ¿Qué prevalecerá a la postre? ¿Este ir y venir de aquí para allá o bien el lento, sangriento y doloroso progreso hacia una sociedad estable (y todo lo libre que permite la jaula económica en que se halla encerrada) que nuestros vecinos y parientes alcanzaron hace muchos años y, con toda seguridad, de manera más suave e incruenta? (p. 131)

La segunda proposición nos señala el indicio de la memoria discursiva republicana que vuelve a traer en este artículo los problemas de la heterogeneidad, en sentido positivo, la necesaria afirmación política a favor de la Democracia y, por último, la reivindicación de una nueva forma de memoria que ya no busque lo definitivo sino que ahonde en la microhistoria de ese misterio llamado "España" y cuyo resultado vuelva al desencanto; lo mismo que la generación del ` 98.

Así pues ¿a qué viene esa insistente demanda por la definitiva novela de la Guerra Civil española, por la novela del postfranquismo, por la cultura de la

\footnotetext{
${ }^{21}$ Una de las reflexiones vuelve al tema de España, interrogado ya por J. Ortega y Gasset: "España, como pueden ustedes leer en el programa introductorio de este Simposio, continúa siendo un enigma, una realidad incomprendida para muchos" (BENET, 2007, p.131)
} 
próxima década? [...] Poco a poco, la novela en España, como en cualquier otro país, irá a ocupar su específico lugar para cumplir su específica misión: dar testimonio de la poca fortuna y mucha desgracia que el hombre puede esperar lo mismo en 1980 que en 1680. (2007, pp.135-136)

Obviamente, la referencia vuelve a caer en el paradigma del escritor y de la obra en el Quijote. Esta obra es el pilar del proyecto benetiano y le sirve, además, para mencionar el deber y ese deber es un pilar moral, que durante el período franquista, ha sido mediocre. Literatura, entonces, entra en el terreno de la ideología, en la esfera de las ideas pero esa esfera necesita una correspondencia social en el sentido moral. Al respecto, los dos artículos, escritos por Carmen M. Gaite, que acompañan la edición de La inspiración y el estilo de Alfaguara (1999) ${ }^{22}$, focalizan en la articulación espacio-temporal de la propuesta, mediante la cual Benet hacía ingreso a las Letras, que vio la luz en 1966 y fue publicada por Revista de Occidente. En esos textos, cumple una función vital la consideración del espacio. La memoria de la cartografía madrileña, que veremos al detalle en Otoño en Madrid hacia 1950 (1987), prioriza la tertulia de Gambrinus o al cocina de la misma Gaite en el ambiente clausurado del franquismo. La taberna, como figura, le sirve a Benet para criticar la forma estilística, pasando por el manierismo y la Ilustración, hasta llegar a la Postguerra. Esta imagen supone lo prosaico, carente de estilo, popular en un sentido poco valioso y no literario. En cambio, el Grand Style, se sostiene por la tensión necesaria entre la inspiración y el estilo. Éste no supone la vocación del realismo de la Postguerra sino la comprensión del mundo para la resolución de problemas de manera subjetiva. Este último punto es central para comprender el proyecto benetiano y se grafica a partir de la figura del rapsoda ${ }^{23}$

Yo creo que en esta relación entre el escritor y su público- sea éste de carne y hueso o un mero supuesto al que el escritor no llega nunca a conocer de hecho- hay una ficción: en realidad son dos lectores los que hablan, dos degustadores; lo que menos interesa en esa relación es precisamente la categoría escritor, qué es lo que hizo, lo que quiso hacer y lo que hará para escribir. (1987, p.251)

La representación de sujetos, necesariamente entendidos como lectores, compartiendo un horizonte de expectativas. La memoria tiene su asiento en la Guerra civil española, la Postguerra y la Transición. Ese amplio campo nos deja, especialmente en sus ensayos, con mayores incertidumbres que certezas. Quizás, como explica Ignacio Soldevila Durante (1982)

La obra de Benet es un perpetuo interrogarse sobre todo. Es una obra de preguntas, de planteamientos. En ningún caso de respuestas... El autor se encierra en el barril de Diógenes. Ese barril y las cuatro paredes de su memoria son todo lo que necesita para dedicarse a su infatigable pesquisa, a un abrumador interrogatorio... De un laberinto no se puede sacar una explicación: se entra en él y, con suerte e hilo de Ariadna, se sale uno. Su secreto no es la bestia que yace en su centro, porque, para empezar, un

\footnotetext{
${ }^{22}$ Ambos textos son el resultado de dos conferencias pronunciadas por la autora los días 2 y 3 de julio de 1996 en el aula Francisco de Vitoria de Salamanca. Allí, Carmen M. Gaite participó en el Curso superior de Filología Hispánica que organizó dicha Universidad bajo el título "Juan Benet, espacio biográfico, universo literario".

${ }^{23}$ El punto referido a la subjetividad puede verse en una carta, dirigida a Carmen M. Gaite, el 11 de junio de 1965.
} 
laberinto no tiene centro; su centro es la sinrazón. (p.96)

Quizás el hilo de Ariadna sea adentrarse en esa relación memoria/historia/literatura que ocupó tanto la novelística como el campo ensayístico benetiano. Y el monstruo es el minotauro resignificado en la simbología del poder que nos lleva a la disputa por el sentido político de la memoria del franquismo, pasando por la guerra civil. Su centro no es la sinrazón sino la búsqueda de razón. Como repliegue, el tonel de Diógenes lleva también su gesto deconstructivo. Vale recordar la búsqueda de los otros hombres que Diógenes emprende con su antorcha y cómo polemiza con Sócrates. Por último, el laberinto proporciona una salida que se resuelve con la puesta en ficción de ambos lectores a la que hicimos referencia. Memoria como imaginación, como transformación del tiempo en existencia. Memoria también como construcción de una identidad colectiva que sirve al presente en tanto condición de una ética y una moral.

A continuación, analizaremos la propuesta de E. Runia (2006) para, luego, abordar, las características de la memoria amenazada, como la define Tzvetan Todorov (2000) a partir del Franquismo. Desde diferentes posturas, veremos los tipos de discursos que engendran la puesta en memoria: el del testigo, el del conmemorador y el del historiador.

\section{Las narrativas identitarias: el sentido conmemorativo de la Historia}

El hombre que oye, que es testigo, que ve, que sabe y que no habla... es culpable

Levítico.

En un trabajo de reciente publicación, E. Runia ${ }^{24}$ remarca la importancia en los relatos traumáticos de cómo narrar la experiencia de la memoria traumática en un sentido que no es ya, para la filosofía de la historia, simplemente cuestión de archivología o producto del morbo. El discurso de la Historia, especialmente para la narración de eventos traumáticos, debe necesariamente volverse literario porque la conmemoración deviene inevitablemente retórica. Allí donde debiera triunfar el silencio del no decir, muy parecido al que propone Adorno luego de Auchwitz o el ya mencionado de Semprún en La escritura o la vida, la Historia necesita representar actancialmente la memoria traumática. Esta conciencia histórica se corresponde con un deseo de conmemoración. Aquí debe entenderse que la oposición planteada entre memoria e historia, se sitúa en el debate entre Historia y conmemoración. Nuestra segunda antítesis afirma, entonces, que el discurso de la historia funciona en el despliegue opositivo de estos dos términos. Contra la práctica positivista de la historia, la conmemoración implica siempre la valoración de actos humanos contra actos de Dios o propios de la naturaleza, como los desastres naturales. Porque en estos actos es donde los sujetos se reconocen como humanos. La habilidad para la puesta narrativa de la historia consiste, según E. Runia, de tres cuestiones: aquellas cosas de las que nos enorgullecemos, aquéllas de las que nos avergonzamos y, por último, aquellas transformaciones miméticas a partir de las cuales nos embarcamos en lo inimaginable. Centrándonos en este último elemento, la historia narrativa nos devolvería a esa hermosa metáfora que acuñara Humboldt, donde abandonamos los palacios y regresamos a

\footnotetext{
${ }^{24}$ Burying the dead, creating the past. Ponencia presentada en el II Congreso Internacional de Filosofía de la Historia. Reescrituras de la Memoria social. Buenos Aires, octubre de 2006.
} 
nuestras "homely huts" porque el autoreconocimiento nos lleva a ese común denominador llamado humanidad. El famoso memory boom es un fenómeno único sólo si tenemos en cuenta la ambigüedad de no poder distinguir en el siglo XX entre la memoria por escasez y la memoria por exceso. La segunda supone un problema psicológico que consiste en reponer y superar el trauma, la primera, por el contrario, es propia de una nostalgia ontológica (Ontological Heimweh) que necesariamente lleva a la actividad histórica por la misma necesidad de rememoración. De esta manera, Runia llega a la conclusión de que la escritura histórica responde a nuestra facultad de externalización. Esta facultad vuelve a desplegar la idea que propone G. Vico a propósito del sentido de lo humano por cuanto una de las externalizaciones básicas y más fundamentales está constituida por el ritual del entierro. Explica G. Vico:

Humanity had its origins in humare, to bury. The Athenians, who were the most human of all nations, were (...) the first to bury their dead. (...) What a great principle of humanity burial is (...) imagine a feral state in which human bodies remain inburied on the surface of the earth as food for crows and dogs (...) Men will go about like swine eating the acorns found amidst the putrefaction of their dead. ${ }^{25}$

En este sentido, el entierro supone dos motivos de relevancia: la cercanía y la perpetuación. El muerto es un modelo del cruce entre presente y pasado y es un modelo de no olvido a futuro. El muerto genera tradición y es, por esto mismo, que el muerto se vuelve la metáfora esencial del discurso de la historia. Hacer historia supone ese ritual del entierro que nos lleva a construir el pasado a partir de las representaciones narrativas. La historia tiene, luego, una utilidad. Como señala R. Belvedresi ${ }^{26}$, la misma sirve 1) para no repetir el pasado; 2) para dar cuenta del progreso humano; y 3) para justificar un determinado estado de cosas. Para el caso que nos ocupa, el escrito histórico debe moralizar para advertir acerca de los errores del pasado; debe, también, dar cuenta de cómo ha evolucionado eso que se da en llamar, en nuestro análisis, por ejemplo, España y memoria discursiva republicana. Y, por último, debe legitimar -y es aquí donde entra en juego la aplicación necesaria de la representación o razón imaginativa a través de la ideología- el estado democrático en detrimento de los nacionalismos fascistas. En este momento entran en juego las luchas por el poder de la representación y de las versiones interpretativas que más se ajustan al sentido histórico que haga justicia al pasado. La noción de justicia, para el caso que analizaremos basado en un escrito histórico que pretende instruirnos acerca de la Guerra civil española, es central por cuanto representa la lucha de poder entre dos memorias discursivas: la republicana y la nacionalista.

2.1 Abusos de la memoria: discurso, utilidad, deber.

Una de las preocupaciones centrales que subraya el artículo Los abusos de la memoria de T. Todorov tiene que ver, por un lado, con los usos y abusos que de la memoria colectiva e, incluso popular, han hecho los regímenes totalitarios del siglo XX; por otro, con el problema de la utilidad de la memoria, con el para qué social y moral de la memoria y el olvido. Volvemos sobre este último par dicotómico, al menos en apariencia, puesto que el olvido es parte

\footnotetext{
${ }^{25}$ Scienza Nuova, par.537 e 337.

${ }^{26}$ Consideraciones acerca de la utilidad de la Historia. Ponencia presentada también en el II Congreso Internacional de Filosofía de la Historia. Reescrituras de la Memoria social. Buenos Aires, octubre de 2006.
} 
indisociable de la memoria y viceversa. Y ya que la memoria funciona como una especie de verdad histórica, es comprensible que está revestida por luchas de poder. En el caso de España, tras la guerra civil, el olvido tuvo su asiento en la selección de una memoria imperial y épica, en la censura de lenguas opuestas al castellano castizo, en la desaparición de toda huella de una memoria republicana, incluso categorizándola y unificándola bajo el término despectivo "rojo". La supresión y la conservación establecen una relación dialéctica; ahora bien, cuando se decide qué se suprime y qué se conserva, nos encontramos frente a decisiones políticas y es necesario analizar sus causas que responden también a una utilidad de la memoria ${ }^{27}$. Señala T. Todorov que, cuando el acontecimiento del pasado tiene naturaleza trágica, el derecho de saber la verdad o las verdades, se vuelve un deber, que es el deber del testimonio. Tras la muerte de Franco, ese deber, si bien auscultado por el pacto de la Transición, se tradujo en la emergencia del género testimonial, autobiográfico, al que se sumaron numerosos simposios, encuentros y tertulias cuya función era la de rescatar las memorias, las verdades ya no sólo de la Guerra civil española, sino de la dura Postguerra, con los exiliados, los maquis y los topos. Podríamos decir que desde 1939, año de la victoria, el lugar de la legalidad democrática, con su lógica contractual, quedó anulado en pos de una legitimidad que proviene ante todo de la tradición imperial. Así las leyes del franquismo reposaban en la supresión de la memoria del republicanismo liberal y en la conservación de la memoria de Primo de Rivera y los RRCC. Ahora bien, si estos usos corresponden a la llamada memoria oficial, ¿cuál es el criterio por el cual distinguimos entre su buen o mal uso? Un criterio posible es aquel que opone la condición de humanidad; es decir, si el criterio es anular la memoria vencida por medio de la guerra, claramente, catalogaríamos la acción como un mal uso de la memoria. Pero también, podemos tener en cuenta el criterio que analiza el carácter del testimonio. Los acontecimientos pueden ser leídos de manera denotativa o, como prefiere T. Todorov, literal o de manera connotativa o ejemplar. La memoria literal refiere a su significación denotativa; es decir, no buscar en sí misma moralizar y tiene carácter intransitivo puesto que prevalece en su literalidad. La regla que lo determina es la de la contigüidad entre el acontecimiento del pasado y el momento del TO presente. Es un relato individual y que es contenido en una esfera privada de comunicación. Se aleja de las implicancias sociales y su sentido puede restringirse a la metatextualidad, justamente por ser tomado como una singularidad.

La memoria ejemplar, en cambio, si bien no niega la individualidad del relato testimonial, tiene una función inclusiva puesto que la integra al conjunto de singularidades como un punto de vista que entra en intersección con una generalidad. El testimonio, en este caso, busca patrones similares que ayuden a comprender un acontecimiento traumático aunque sus agentes y algunos detalles sean diferentes. Esta memoria no rige el espacio de lo privado sino el de la esfera pública; se vuelve, inevitablemente, un exemplum ${ }^{28}$ del que se extrae una lección tanto para el presente como para el futuro. El pasado, entonces, adquiere una función social en el principio porque brinda parámetros del buen actuar ya que se apoya no en la contigüidad sino en la semejanza, dada por recursos analógicos. La primera, como señala T. Todorov, porta riesgos porque tiende a perderse en un relato único al que, incluso, se podría justificar, en cambio, la memoria ejemplar, libera porque incluye al otro. Su transitividad es lo que lleva a

\footnotetext{
${ }^{27} \mathrm{Al}$ respecto rescata T. Todorov la implicancia de la democracia frente a los totalitarismos nacionalistas: "Ninguna institución superior, dentro del Estado, debería poder decir: usted no tiene derecho a buscar por sí mismo la verdad de los hechos, aquellos que no acepten la versión oficial del pasado serán castigados. Es algo sustancial a la propia definición de la vida en democracia..." (TODOROV, 2000, p. 16)

${ }^{28}$ El género exemplum, originariamente medieval, debía dejar una enseñanza o moraleja a propósito del caso presentado de fuerte contenido ético o moral.
} 
entenderla no en términos llanos de "mera descripción" de un conjunto de eventos del pasado sino, por el contrario, en un relato que hace justicia y obliga al compromiso. Por eso la ley es impersonal, justamente porque hace de un relato subjetivo una generalización, donde importa que el acontecimiento en tanto sea juzgado, no se repita.

He hablado de dos formas de memoria porque en todo momento conservamos una parte del pasado. Pero la costumbre general tendería más bien a denominarlas con dos términos distintos que sería, para la memoria literal, memoria a secas, y, para la memoria ejemplar, justicia. La justicia nace ciertamente de la generalización de la acusación particular, y es por ello que se encarna en la ley impersonal, administrada por un juez anónimo y llevada a la práctica por unos jurados que desconocen tanto a la persona del acusado como a la del acusador. (TODOROV, 2000, p. 32)

De esta forma, tomar un acontecimiento de manera singular y superlativa no deja ver qué características comunes comparten con otros presentes; así se pierde la capacidad de aprender del pasado para resolver acontecimientos presentes. Entonces, la recuperación del pasado no está buscando la verdad -cuestión que se reduce a la verosimilitud- sino al bien. Así, no habrá un exceso de memoria en oposición a una supresión de la misma sino, por el contrario, entre un buen o mal uso en ambas. El mal uso está ligado en los regímenes totalitarios a estrategias concretas de control social y prohibición. La primera consiste en la desaparición de huellas: monumentos, aparatos de Estado, cadáveres, documentos, etc. para imponer en otros bajo la insignia oficial. La segunda, propiamente de control, se basa en la intimidación de la población y la prohibición de adquirir o hacer circular determinada información. Más aún si lo pensamos para la etapa de Postguerra, donde la misma autarquía subrayaba la clausura. Otra estrategia consiste en el trastocamiento de la realidad mediante eufemismos: los llamada cruzada, el término rojo, la revolución o los paseos. Por último, la mentira entendida como propaganda: los grandes afiches mostrando una España una o los XXV años de paz mientras se seguía castigando a los republicanos. Si los acontecimientos dejan dos tipos de huellas, unas denominadas "mnésicas" y otras "materiales", existen procedimientos para hacer revivir el pasado en el presente: 1. El establecimiento de los hechos del pasado supone una construcción, basada en la selección y en la jerarquización. 2. La construcción del sentido es inherente al relato testimonial por cuanto los acontecimientos deben ser interpretados. Aquí no se trata de comprender como medio para justificar, como decía P. Levi sino de analizar el mal para llegar al bien ${ }^{29}$. No se produce una verdad sólo por adecuación, como en el primer nivel, sino por desvelamiento, lo que ahonda en la psicología social. Es por eso que es intersubjetivo y nunca referencial. 3. La puesta en servicio de la memoria corresponde al reconocimiento y la interpretación. Los acontecimientos son relatos; pueden ser heroicos o victimistas.

Sobre este último punto nos gustaría realizar una breve reflexión. El estatuto de víctima, sin lugar a dudas, es el lugar privilegiado del relato testimonial. El relato heroico es, generalmente, propio del discurso histórico oficial. La víctima tiende, comúnmente, a la protesta y al reclamo y es más probable que la memoria juegue un rol mucho más central que en

\footnotetext{
${ }^{29}$ Explica T. Todorov: "Todos los hombres son potencialmente capaces del mismo mal, pero no lo son efectivamente, pues no han tenido las mismas experiencias: su capacidad de amor, de compasión, de juicio moral ha sido cultivada y ha florecido o, por el contrario, ha sido ahogada y ha desaparecido" (Memoria del mal, tentación del bien. Indagación sobre el siglo XX, 2000, p. 151)
} 
el histórico. Este último, mientras intenta la objetividad, deja para el testimonio, el desarrollo intersubjetivo Todorov (2000) lo explica mediante la analogía de la pasión de Cristo por cuanto la víctima necesita del reconocimiento de los demás pero también de la idea de misión moral que conlleva el sufrimiento que ya no sólo de sabe individual sino social. Al respecto tres son los grandes discursos que utilizan las huellas del pasado para influir en el presente: el del testigo, el del historiador y el del conmemorador (p. 155). El discurso del testigo es aquel cuyo sujeto productor reúne los recuerdos para darse una identidad. Es un trabajo individual que puede estar o no acompañado de huellas materiales. Es, en este caso, metatextual; no hay quien condicione la tarea porque nadie puede refutar un acto singular. El historiador, como hemos analizado ya, representa a una disciplina y busca un discurso asimilable a una verdad, aunque en realidad, apunte a una adecuación verosímil. Busca la construcción de sentido objetivo y se opone al testigo sólo en la esfera y en la construcción de sentido.

Ahora bien, cuando el discurso del testigo merezca ser tenido en cuenta en la esfera pública, se transformará en discurso testimonial. Ambos se enriquecen puesto que el testimonio se jerarquiza y legitima por le punto de vista mientras que el discurso histórico lo ordena y lo hace inteligible. Por último, el discurso del conmemorador comparte con el testigo el interés propio de su tarea pero, al igual que el historiador, su discurso se produce en la esfera pública y se presenta con un énfasis mayor de verdad que el frágil discurso testimonial, a la vez que refleja la imagen de una sociedad. Los aparatos ideológicos de Estado como la escuela o los medios de comunicación son los espacios por excelencia para la difusión de este tipo de discursos. La conmemoración simplifica nuestra visión del pasado mientras que la historia la complica. Busca venerar héroes y aborrecer tiranos y así jugar un rol político en el presente mientras que la historia sólo accede a su estatuto pretensión de objetividad sin explicitar intereses. En el apartado subsiguiente, profundizaremos en las características de discursos de memoria, prestando especial atención al carácter tanto ético como moral.

\title{
3 Usos conmemorativos del testimonio
}

\author{
Para escribir este libro he usado el lenguaje mesurado \\ y sobrio del testigo, no el lamentoso lenguaje de la víctima... \\ creo en la razón y en la discusión como supremos instrumentos \\ de progreso y por ello antepongo la justicia al odio. (LEVI, P.,1986, p.185)
}

Primo Levi es el testigo por excelencia. Su relato de la experiencia del Lager ${ }^{30}$ no tiene como punto central contar la historia del sobreviviente sino, por el contrario, dar testimonio. No busca posicionarse como víctima; busca la razón de los hechos y la discusión acerca de las víctimas y los victimarios; busca un lector a quien concientizar sobre los males del Holocausto. En esas reflexiones, encontramos un punto de partida para analizar la experiencia del testigo del periodo franquista por su intención educativa. La amenaza de los totalitarismos necesita de ese desciframiento del mal, de la descomposición del recuerdo para integrarlo al tamiz de la memoria porque dicho mal perdura como amenaza en el presente, no se consumió en el pasado. Y es el factor educativo lo que a ambos testigos les interesa ya que allí no hay engaño. En la veta subjetiva, sin el disfraz de la objetividad historiográfica, están los verdaderos relatos. Y es la conmemoración de la víctima lo que ambos buscan a partir del testimonio.

\footnotetext{
${ }^{30}$ Lager fue un término usado para definir los asentamientos en los campos de concentración del Holocausto. En su campo semántico referido a lo bélico admite las definiciones de guarida y campamento, entre otras.
} 
En principio, el relato testimonial busca clasificar por definición. Para Primo Levi la palabra del superviviente limita con el silencio del musulmán. Ese límite transita una verdad subjetiva. Los judíos llamaban musulmanes a quienes tocaban fondo y no volvían o volvían mudos.

Su vida es breve pero su número desmesurado; son ellos los müselmänner, los hundidos, los cimientos del campo; ellos, la masa anónima, continuamente renovada y siempre idéntica, de no-hombres que marchan y trabajan en silencio, apagada en ellos la llama divina, demasiado vacíos ya para sufrir verdaderamente. Se duda en llamarles vivos: se duda en llamar muerte a su muerte, ante la que no temen porque están demasiados cansados para comprenderla (1986, p. 96)

El deterioro físico y psíquico de la corporeidad del musulmán es, sin duda, indicio de su degradación moral. Por eso es un "testigo integral", aquel que en su totalidad ha sido marcado por el mal y su actualidad lleva a la rememoración del mal. Es la presencia de la imposibilidad, aquel que sabe pero es incapaz de comunicar. Para eso está el testigo que hace a la justicia de la memoria del mal para lograr el bien. En el relato de esta puesta en narración del testigo habría que distinguir, sin embargo, tres estadios ${ }^{31}$ : 1. El nivel de los autobiográfico o del sujeto empírico. 2. La identidad narrativa que es la construye el imaginario social necesario para la justicia. 3. La identidad meramente del sujeto autor, que organiza e incluye a los otros dos niveles. (ROBIN, 1996, p. 61) Esto hace del relato testimonial, un discurso puesto en función del conocimiento. La comprensión a la que hace referencia P. Levi, supone un conocimiento del origen, de las causas para prevenirlo en el presente. Por eso, Benet es el testigo directo del franquismo e indirecto de la Guerra civil española. No obstante, el relato moral de esta última invade constantemente el testimonio del presente. El deber de conocer implica el uso de la subjetividad. Deben ser los propios sujetos en su función de testigos quienes brinden un testimonio porque, de esa manera, humanizan al deshumanizado por el mal de los regímenes totalitarios. Si la víctima, especialmente figurada por el musulmán, se encontraba absolutamente deshumanizada por lo tecnológico del exterminio y la degradación moral que supuso, es un deber del testigo que puede comunicar, hacer del recuerdo, un testimonio moral porque así estará haciéndose cargo de la inhumanidad del otro y, con su voz, intentará devolverle la integridad moral y el estatuto de sujeto político. Una de esas estrategias es la de distinguir entre víctimas y verdugos: "No sé ni me interesa si en mis profundidades anida un asesino, pero sé que he sido una víctima inocente y que no he sido un asesino; sé que ha habido asesinos y no sólo en Alemania, ...y que confundirlos con sus víctimas es una enfermedad moral" (LEVI, 1986, p. 42).

Deberíamos entender, entonces, que la memoria histórica no se trata de ver cómo le fue a cada cual en la Guerra Civil o durante el franquismo, sino someter a discusión o, como quería Levi, a la razón, la reflexión política sobre una violencia pasada sobre cuyo olvido, o su elipsis, se ha construido el presente. Para lo mismo, la memoria es justicia puesto que la reconstrucción pasa por la identidad colectiva; es decir, una política que, alejada en nuestro caso, del pacto de

\footnotetext{
${ }^{31}$ Régine Robin centra su interés en el problema de la identidad y en su transformación frente a la pérdida; en este caso, la nueva identidad del testigo o de la víctima, que no permanecen estables. Cuando ese terreno se encuentra amenazado, ahí se afirman las identidades narrativas (RICOEUR, 1985) con marcadores de verdad, adecuación o pertinencia para lograr un efecto de realidad.
} 
la transición, sea de reparación, reconocimiento y reconciliación. Y en el relato es donde entra a jugar el lector. Para Levi, los jueces son los lectores. Memoria de la injusticia como condición de la justicia. Por eso, para Benet también, el relato testimonial, lleva a preguntarse con el lector sobre el período franquista sin alejarse del momento de producción de relato. Avishai Margalit (2002) luego de establecer una relación triádica entre recuerdo, interés y ética, se vuelca sobre el concepto de testigo moral que es el que nos interesa en el análisis del relato testimonial porque es uno de los administradores del recuerdo colectivo. El testigo moral es quien experimenta los sufrimientos, de manera propia u ocular y quien se encuentra en riesgo. En el caso del relato que analizaremos en el siguiente apartado, se dan las características de "testigo" y "sujeto moral" sin ser el relato producido por un "testigo moral". Al respecto, no es quien porta la esperanza en su sentido teológico sino quien debe sobrevivir, a diferencia del ejemplo del mártir, para relatar un estado de acontecimientos, hacerlo inteligible y legitimarlo. Por eso el uso de la primera persona para poner el énfasis en la experiencia de la exposición frente a ese mal. La autenticidad en la narración hace que en el relato benetiano se conjuguen la representatividad de una comunidad y el deber moral de la enseñanza del mal. La representatividad está dada por su pertenencia generacional: la de los intelectuales del medio siglo y el deber moral ${ }^{32}$, implícitamente narrado, por la prevención de los totalitarismos como el del franquismo que parte de un interés tanto personal (Anteilnahme) como objetivo (Interesse). Ambos debieran ser correlativos para lograr el bien puesto que todo objetivo tiene su raíz personal para volverse auténtico. Así, en los relatos testimoniales en los que Juan Benet se ubica como un testigo moralizador de la etapa franquista, vemos cómo oscila entre los territorios de la moral y de la ética para alertar sobre el mal del nacionalismo católico.

Manuel Tuñón de Lara, que pasó más de treinta años en el exilio, recordaba, en su "Última clase magistral", que para Bloch "la historia es la ciencia del devenir de los hombres en el tiempo, que viene de ayer y va hacia mañana". Eso obliga a los pueblos a recuperar su memoria colectiva cuando ésta les ha sido arrebatada, ocultada o falsificada. España ha pasado por eso como otros pueblos, como el pueblo alemán, como ha pasado con los países del Este, etc. (DE LA GRANJA Y TAPIA, 1993, p. 454). Pero España presenta unas variantes distintivas: en principio, el triunfo en 1939 del fascismo nacionalista y católico y sus reformulaciones, con leves cambios hacia la década de 1950, el ingreso del Opus Dei pero manteniendo la imagen y el poder de Francisco Franco. Esta variante vulneró en su momento, y lo sigue haciendo hasta hoy, la función -según Javier Tusell- de la memoria "como elemento que configura espiritualmente una sociedad, y, además, es indicio de los cambios que en ella se producen" (2002, p.11). Y añadía Tusell, a continuación, que la Guerra civil española contribuyó durante años a mantener al régimen y sustentar la Transición recordándole a la clase política que se podía producir nuevamente un conflicto civil como el de los años treinta (TUSELL, 2002). Sobre el pacto de olvido de la Transición- que, para Max Aub, significaba, negativamente, contemporizar ${ }^{33}$ - los escritores buscaron la construcción del pasado, la activación de la memoria,

\footnotetext{
${ }^{32}$ Nos basamos en la distinción de A. Margalit entre moral y ética. Mientras la primera se corresponde con lo que el autor llama "relaciones sueltas", no marcadas por una cercanía; la segunda se corresponde con las llamadas "relaciones estrechas". Para lo mismo se basa en la parábola del buen samaritano (Lucas 10, 29-37) a partir del término "prójimo".

33 "La actualidad es gran comedora. Sin embargo, el hombre lo es porque, entre otras cosas, no olvida. Pero la política le lleva mil veces a borrar palabras y hechos de la memoria porque ésa es la medida de las conveniencias. Los buenos políticos suelen tener mala memoria; mas el escritor vive de ella y por ella se hace. Divergencia fundamental que puede explicar el fracaso de tantos escritores, si lo son de veras, metidos a políticos. Las obras sólo quedan de la voz de la fama; y nosotros luchamos contra el olvido. Los políticos llegan al recuerdo -que es la Historia- a fuerza, muchas veces, de lo que llaman contemporizar; es decir, ser contemporáneo, olvidar lo pasado
} 
ya sea con la Guerra civil española en primer plano o como telón de fondo, con un condensado como Región ${ }^{34}$ o con la labor de recordar en relatos testimoniales. A diferencia de toda Europa donde el mal de los fascismos se hizo evidente, en España quedó oculto por un régimen que duró casi cuarenta años. Por eso los testimonios se orientan al bien, a la manera aristotélica, a la compulsión del testimonio. Porque, quizás, contradiciendo a Theodor Adorno y apoyando la tesis de Günter Grass, es una obligación seguir escribiendo, continuar recuperando la memoria del pasado traumático para que no acabe nunca y sirva de alerta en el presente y el futuro. A continuación, analizaremos el caso de testigo moralizador en un relato testimonial de Juan Benet que recupera la memoria de los vencidos, no sólo los del campo intelectual- Baroja, Caneja- sino aquellos propios de la microhistoria- la gente común- durante el franquismo, como aporte fundamental a la memoria colectiva.

\subsection{Las memorias de "lo invicto": Otoño en Madrid hacia 1950}

El debate que, tras la muerte de Franco, no se pudo realizar, empañado por la ficción superadora de la Transición, se vio intensificado por el boom de relatos testimoniales. Emilio Silva escribía en El País del 15 de diciembre de 2002 que la recuperación del pasado está ligada al reconocimiento de las víctimas y al conocimiento del hecho ${ }^{35}$. Estas relaciones marcan la necesidad de una generación de rescatar, de dialogizar la memoria, la identidad de aquello que ha permanecido invicto. Como explica Francisco Caudet (2008), no basta con desenterrar muertos, asignarles un nombre y pasarlos a la memoria del pasado. Los muertos tienen familia y proyectos políticos opuestos al régimen franquista del nacionalismo católico. Invicto en el sentido en que un conjunto de relatos puede tener hacia 1987. Acumulación de piezas aparecidas antes en libros colectivos y papeles periódicos, pese a la cronología intermitente en que fueron escritos, entre 1972 y 1986, a la consideración de Otoño en Madrid hacia 1950 como un libro menor. Madrid y San Sebastián, la guerra y la sentimentalidad durante el franquismo: los recuerdos de "El Mirlo Blanco", Pepín Bello, Dominguín, la tertulia, Baroja, Caneja. Invicto en el retrato ético y moral de los tipos humanos que han permanecido en la memoria, victoriosos por fuera de la memoria oficial. En su doble significancia, también por ser la republicana una memoria que ha quedado intacta o, como diría J. Benet, en penumbras. Otoño en Madrid desvela la memoria de la España franquista, una memoria que alejándose de los grandes relatos, devuelve la mirada a la microhistoria, a la intrahistoria de sujetos que han de volverse históricos. El testimonio en ese cruce entre la historia y la memoria, inventa porque, como explica Benet "no obedece a otra regla que a la de romper el círculo de lo inventado". Ese

con tal de asegurar el paso inmediato, transigir, condescender, mentir. No son estas prendas del escritor, como no sea por juego" (AUB, 2002, p. 134).

${ }^{34}$ Benet construye un espacio imaginario llamado Región que funciona, en realidad, como condensado ideológico más que como cartografía, de la memoria discursiva republicana. Ver: Herrumbrosas lanzas.

35 "El proceso de recuperación de la memoria y del conocimiento de la dura realidad de la guerra civil y del franquismo evidencia la necesidad que tiene la sociedad española de conocer su historia reciente. El impacto causado por la exposición sobre el exilio, realizada recientemente en Madrid (Exilio 2002), la apertura de las fosas comunes o el documental sobre los niños secuestrados a las presas republicanas, es un reflejo del desconocimiento generalizado de esa parte de la historia. Amplios sectores sociales se encuentran sorprendidos por lo que están conociendo, y los que ya lo conocían y lo padecieron están necesitados de reconocimiento, de ver ese reflejo de sus vidas en espacios públicos. Si no seguimos el proceso de países como Alemania o Francia en la revisión del pasado relacionado con el fascismo, y no se habla- el subrayado es nuestro- y se cambia el significado de ese pasado y de nuestra relación con él, seguirán en nuestra identidad y habitando en nuestro inconsciente colectivo efectos que causó directamente la dictadura." (SILVA, 2002) 
círculo del franquismo se rompe con la frontera que va desde lo privado a lo general. Allí, la voz del testigo se materializa para ser una voz entre las voces de la memoria colectiva.

3.1.1 Pensar la Historia, escribir la memoria

\author{
Un pequeño volumen de memorias en cierto modo \\ contrapuesto a mi- por el momento vigente- propósito de no escribir \\ nunca memorias ni diario ni cosa parecida. \\ (BENET, J. Prólogo a Otoño en Madrid hacia 1950, p. 13)
}

La memoria, como describe J. P. Vernant ${ }^{36}$ supone un viaje al pasado pero ese pasado, como canta Mnemosine, es siempre una mirada sobre lo invisible y una geografía de lo sobrenatural. Este carácter ficcional de la memoria relatando el pasado, de la memoria buscando el pasado desde esa reminiscencia aristotélica actualiza el debate inevitable acerca de la escritura de la historia y, más específicamente, del problema epistemológico de la producción de sentido en la hermenéutica de los relatos del yo. Otoño en Madrid hacia 1950 es, sin duda, un conjunto de relatos que intentan explicar la Historia de la inmediata Postguerra franquista, es decir, un programa de textos literarios, donde la puesta en escena de un yo, rompe a la vez que inaugura el relato fundacional de otra historia, esa que quiebra la tesis 1.5 con la que $\mathrm{F}$. Ankersmit anuncia la muerte de la hermenéutica epistemológica, aquella que analizábamos con el MLA (Modelo de ley aclaratorio), para dar paso a la hermenéutica analítica. En este sentido, el problema central es el que está implicado en este debate y que ha tenido en España, respecto del boom de las narrativas históricas, un anclaje decisivo para reflejar, en realidad, un debate más profundo: el de una Historia que nunca termina de contarse, que sigue eligiendo sus referentes, sus espacios y sus memorias que ya no han de ser ni oficiales ni una sino dialectales, heterogéneas y varias. El problema central es entender que el referente fáctico es también una construcción del punto de vista, que la noción de verdad irrevocable se anula en la polisemia intrínseca a la memoria y que las imposibilidades de ese mismo referente son, ante todo, posibilidades discursivas.

El debate de la Historia y, por ende, de la Memoria verdadera, encuentra en este texto de Juan Benet, una posible explicación que, además, de ofrecer un punto de partida genérico, brinda y es esto lo fundamental, un panorama ideológico de recuperación del republicanismo que estará atravesada por lo que, para algunos teóricos, implica la influencia de la concepción de la postmodernidad: en la muerte del sujeto y de la representación (LYOTARD), en la muerte de la historia (FUKUYAMA) -y que servirá a comprender el estadio de la historia en la narrativa benetiana, marcada por la Guerra civil española frente al de la prehistoria-, en el imperio de la sincronía y la simultaneidad (JAMESON), en la disolución de la obra-texto (DERRIDA) y en la polisemia interpretativa (ECO).

Sin embargo, se mantendrá como problema central, el de la recuperación de la memoria y la tradición valorizada del republicanismo frente a la tradición criticada del franquismo. Estos polos marcan todo el trayecto narrativo que se verá configurado en tiempo y espacio en las novelas a partir de la reformulación amplificatoria que proporcionan los ensayos sobre la memoria, la historia, la idea de escritor y la literatura, junto con las problemáticas en torno de la moral, la ética y la memoria colectiva.

\footnotetext{
${ }^{36}$ J. P Vernant en "Historia de la memoria y memoria histórica", desarrolla la concepción de la memoria ligada a la creación (poiesis) y aquí es donde la narrativa cobra importancia por su carácter ficcional.
} 
Es por eso que nos interesa esa relación entre los ensayos, incluyendo los relatos testimoniales, tanto como las novelas. Si, con sus ensayos históricos, Benet explicitaba desde su lugar de enunciador objetivo, con ayuda de las parentéticas de matiz irónico, la actualización de la memoria histórica, en Otoño en Madrid hacia 1950, mediante la presencia del sujeto en primera persona, subjetiviza el relato para volverlo experiencial, siendo su cercanía a los hechos de matiz ético. Tres ejes resultan esenciales: el anclaje temporal de 1950, los condensados ideológicos República, Franquismo, Guerra civil en tanto servirán para explicar los estadios de prehistoria e historia en las novelas y, por último, el marco espacial, la ciudad madre, Madrid, que cubre y despedaza, esos topoi discursivos que señaliza las huellas de una ciudad que ha sido quebrada en su dialéctica interno/externo y público/privado.

\subsubsection{0}

\section{...Y sobre todo el vértigo del tiempo, el gran boquete abriéndose hacia dentro del alma...} (GIL DE BIEDMA, 1975, Las personas del verbo, p. 37)

Los años de la inmediata Postguerra encuentran su anclaje en lo que funciona como un fuerte quiebre respecto de la ideología republicana. La propuesta del racionamiento ${ }^{37}$ es central como productora de ideología y la ciudad franquista se escenifica como centro del control y el aislamiento. Señala M. Vázquez Montalbán que

[...] como concepción total de la cultura, el franquismo al día siguiente de su victoria plantea una política cultural basada en la falsificación del lenguaje y de la historia, el secuestro de la memoria de la España vencida u ortodoxa, el monopolio factual de todo aparato de creación de conciencia y [...] plantea una cultura onmívora, basada en lo épico-imperial (1998, p.61)

En este sentido, "Barojiana”, primer artículo de Otoño en Madrid hacia 1950, ofrece la recuperación de la memoria de la generación del ` 98 y aquí el sentido de la Historia y de la necesidad de historiar ${ }^{38}$, evidencia el primer gesto de la memoria discursiva republicana, con la que nos referimos a un conjunto de enunciados, que la tradición de una ideología reformula en su Historia. Frente a la construcción de héroes del franquismo, la perspectiva de la narrativa histórica de Baroja sirve a los efectos de rescatar la memoria inválida pero invicta de los nohéroes. El héroe sin grandeza, lo que lo vuelve común, la prosa sin brillo, lo que la acerca a los hombres y esa intrahistoria, de la que nos hablaba Unamuno, y que los textos de Benet, en ese juego de presencia-ausencia de la memoria, optan por rescatar del olvido, los referentes del republicanismo, mediante el recurso de la "presentización" como parte del preterizar,

\footnotetext{
${ }^{37}$ Carmen Martín Gaite (1999) en Usos amorosos de la Postguerra española (Madrid: Alfaguara) se refiere a la lógica de restricción y racionamiento en el Primer período franquista, como un ampliación de lo económico a lo sociopolítico.

${ }^{38}$ Utilizamos Historiar en vez de Historizar, término que comporta, desde Mandelbaum, el sentido de analizar la Historia desde sus propias condiciones materiales; en cambio, el término historizar, según Popper, siempre incluye la perspectiva a futuro, donde entra la conjetura.
} 
actualizando siempre un sentido presente a partir del argumento de la continuidad, donde la novela cobra especial atención por su detenimiento "entre dos cortaduras de tiempo" 39 .

$\mathrm{Al}$ igual que en sus novelas, estos textos vuelven al leit motiv de la memoria porque es necesario ver los quiebres ya que, como señala Bergson, "siempre es la parada lo que exige una explicación, no el movimiento". Esta parada, este quiebre en la memoria que supuso la Guerra civil española con la consecuente resultante del franquismo, necesita explicarse una y otra vez. 1950 es quizás una posible explicación que funciona como eje para entender también la construcción de estos artículos ya que ese año se dictamina la obligatoriedad del Documento Nacional de identidad con la huella dactilar del pulgar, lo que suponía un control estricto del ciudadano español. Este quiebre que deja de ser sólo fáctico, es funcional a los efectos de explicar su significación ideológica. Para lo mismo, el ethos discursivo que se elige es el del intelectual crítico quien, siguiendo los lineamientos de $\mathrm{H}$. White, utiliza como recursos tropológicos predilectos, la ironía y la metáfora. Para el anclaje temporal, 1950 y, en especial, los años de transición, determinados hacia 1946, en que tienen lugar los relatos sobre Baroja y Caneja, encuentran su oposición en los usos irónicos respecto del Régimen franquista que, en la mayoría de los casos, aparecen en posición paratáctica, para resaltar la presencia de un sujeto enunciador que deja en claro su opción ideológica, tal como hiciera en dos ensayos anteriores: Qué fue la guerra civil y La cultura en la guerra civil, el primero de 1975, año de la muerte de Franco; el segundo, de 1986. Los usos metafóricos tienen siempre su connotado en la construcción discursiva del republicanismo frente al Régimen, cuyos signos eran siempre asociados al autoritarismo y la decadencia:

A poco que se piense el pastor (se refiere a un policía de tránsito) reúne todos los atributos simbólicos de la realeza, incluso la capa. No muy acusada será la transformación que sufren esos atributos al pasar del rey al agente municipal: el cetro se convierte en porra y el canto en un silbato con que lanzar ese pitido que, en el ambiente ciudadano, no es más que la pedrada que la autoridad dirigirá a la cabeza díscola. (BENET, 1987, p. 62)

De esta forma, los artículos focalizan en la recuperación de una memoria discusiva republicana cuyos héroes son, ante todo, los antihéroes de la Historia oficial, de la España una que es, en realidad, una España dialectal. Este dialectismo funciona contra el aparato del Estado censor franquista, mediante la posibilidad del rumor colectivo que Benet ilustra a partir del análisis de dos planos de la información: uno oficial, engañoso; otro, el del rumor subversivo, "exponente de una realidad que todos los días estaba a punto de romper el frágil cascarón de la censura" (p.23). Las memorias de este relato se articulan mediante procesos de metaforización, generalmente, las metáforas de la enfermedad, como crítica a la España franquista. En un nivel implícito, la estructuración del texto como una "galería de figuras" lo aleja de la intencionalidad semántica de todo relato testimonial que se centra sobre el yo, aunque lo mantenga como hilo conductor. Como explica P. Ricoeur (2000), en correspondencia con el pensamiento de M. Halbwachs (1950), sólo se recuerda desde el punto de vista social "Nous dirions volontiers que chaque mémoire individuelle est un point de vue sur la mémoire collective, que ce point de vue change selon la place que j'y occupe et que cette place elle-même change selon les relations que j'entretiens avec d'autres milieux". (p.33)

\footnotetext{
${ }^{39}$ Esta afirmación permite ratificar la idea de una división temporal entre una prehistoria y una historia que se le opone.
} 


\subsubsection{República, Franquismo, Guerra civil}

Siguiendo la tesis de I. Lotman (1979) ${ }^{40}$, la memoria no sería ese depósito pasivo de la historia oficial sino que contendría, además, la emergencia diseminada de los testimonios y los relatos de esos dialectos de memoria. Si la cultura oficial, durante la dictadura de Franco, provocó claramente la declaración de ruptura con la República, la emergencia en estos relatos provoca el quiebre ideológico resultante en la ficción como ese entramado que permite el sentido histórico. Es por eso que el testimonio, como advertimos anteriormente, permite operar el desplazamiento de lo privado a lo público y en ese desplazamiento reconocer lazos de identidad. La cultura, señala I. Lotman, es una inteligencia y una memoria colectivas ${ }^{41}$. Por lo tanto, para su recuperación, dicha memoria, además de informativa, puede resultar claramente creativa.

Tal es el rol del arte que, además, Benet supo aplicar a las artes plásticas con la técnica del collage, como también lo hiciera a nivel narrativo ${ }^{42}$. Definir, entonces, la cultura como memoria de la colectividad implica plantear "el problema del sistema de reglas semióticas según las cuales la experiencia de vida del género humano se hace culturas" (LOTMAN, 1979, p. 71). Todo acontecimiento que sea concebido en primera instancia como existente, necesita ser identificado con un elemento específico perteneciente a la lengua del mecanismo memorizante.

Desde esta perspectiva, toda cultura se estructura ante todo, en un sistema de comunicación altamente socializado. Por consiguiente, aquellos símbolos que se tomen serán los que respondan a una memoria específica, que no está dada por elección sino por historicidad. Así termina el relato testimonial; con al figura de L. Martín Santos, preguntando ¿a dónde me llevan? Allí permanece el sentido colectivo de las "memorias" en Otoño en Madrid hacia 1950, donde la transmisión de la memoria siempre se hará por selección y relevancia para el momento presente.

En este sentido, es necesario que cada relato tenga su Walpurgisnacht ${ }^{43}$ que, según la teoría de L. M. Santos, todo lo que se considere un buen texto ha de tenerla. Se trata de la necesidad de la vuelta al pasado, de que todo texto se interrogue sobre el pasado y la memoria. No es casual que en Tiempo de silencio, ese núcleo asome en la parte central del texto, parte que, vale aclarar, fue censurada. Y la memoria del republicanismo, como la prehistoria que antecede a la tragedia de la Historia, dada por la guerra civil y perfeccionada por el franquismo, es también central en Otoño en Madrid. Ese centro opera de manera irónica en este texto con "El Madrid de Eloy" y es el punto que revaloriza espacialmente a los espacios clandestinos de dicha ciudad.

Es por esto que los referentes del republicanismo son referentes de la memoria vencida pero invicta: la historia de la literatura, con los relatos de Baroja y Martín Santos y la historia del arte con el rojo absoluto de Caneja ${ }^{44}$, que cambió su forma de pintar al salir de la cárcel. Este

\footnotetext{
${ }^{40}$ Tomamos a I. Lotman por ubicar el análisis de la memoria social dentro de una coyuntura mayor como la Cultura, desde la semiótica cultural.

41 Ver: "La memoria a la luz de la culturología".

42 "Et in Arcadia ego" tanto como "Ensayos de la catástrofe", la primera de 1992 y la segunda de 1984, son algunas de las obras pictóricas de J. Benet de contenido histórico y acerca de la memoria.

${ }^{43}$ Se llama así a las festividades en las que aparecían los muertos vivientes y se rendía culto a Baco , la memoria del pasado en un cruce carnavalesco

${ }^{44}$ Es interesante ver en este artículo cómo no postula ningún extremismo. Para definir a los rojos, postula una
} 
quiebre en las formas, con un Baroja triste y desolado, para quien se utiliza el subjetivema valleinclanesco al igual que el relato de un Unamuno, que muere de tristeza al saber que había acabado la República, se nutre de otros relatos, de esos anónimos republicanos, como Benito, alcalde republicano de su pueblo toledano quien al regresar, salido de la cárcel "no encontró un solo amigo, su mujer se había casado con el alcalde falangista y fue derecho a Carabanchel" (p. 47); la historia del filósofo con el ojo de vidrio que, en un gesto de valentía recurrió a la policía: "Vengo a dar cuenta de mi desaparición, señor comisario" (p.55), la figura de Eloy indagando el sistema en ese juego lingüístico que se titula en el artículo "El Madrid de Eloy", simulando el Paris de Baudelaire o la Praga de Kafka., de manera irónica puesto que España no había logrado estar a la altura de los demás países europeos. Esa huella del republicanismo que culmina con la figura de Luis Martín Santos, a quien se menciona en los ensayos de Puerta de tierra y quien se configura con las construcciones nominales de Arcadia republicana o Hampa en plena transgresión irónica contra el franquismo, como esa utopía, que es necesario recuperar para asignarle un lugar en la memoria de la Historia, que comienza con esa propuesta de una Historia de la Postguerra española a través del rumor, comentada en tantas tertulias clandestinas.

\subsubsection{Los topoi de la Historia}

Esa historia que nadie sabía hacia dónde iba a dirigirse. (BENET, 1987, p.17)

Los lieux de mémoire, según hemos definido, de acuerdo con P. Nora, no sólo representan un cambio de miras y una renovación conceptual en el campo de la historiografía (CUESTA BUSTILLO, 1998, pp.216-218) sino que, en tanto instrumento cognitivo, la noción de "lugar de memoria" se extendió más allá de los límites disciplinares y geográficos en los que se habían gestado. Claro está que estamos trabajando con la construcción simbólica de los lugares de la memoria, con las voces diseminadas y los lugares discursivos que reconstruyen la memoria republicana. Aquí estos lugares se presentan como parte de una ciudad que expulsa, que es la negación de la naturaleza mediante el impulso deshumanizante del hombre. La ciudad estaba rota así como el "ecosistema intelectual", en términos de V. Montalbán, estaba destruido. El skyline de la ciudad franquista no coincide con el modelo que pensaron los griegos: la ciudad como una mujer en reposo que evoca a la Diosa Tierra, liberada de todos los trabajos y la acerca a la fecundidad. La ciudad moderna es el símbolo de la madre, con la bivalencia de la protección y el límite.

Se emparenta en general con el principio femenino. De la misma manera que la ciudad posee a sus habitantes, la mujer contiene a sus hijos. Por esta razón, las diosas se representan llevando una corona de murallas. En el Antiguo Testamento las ciudades se describen como personas. (VÁZQUEZ MONTALBÁN, 1998, p.9)

Pero ese skyline de la armonía griega es parte de la prehistoria republicana, de los recuerdos de infancia, donde la madre España no tenía su sinónimo en Patria, Régimen e Iglesia. El skyline de la ciudad franquista ha roto los lazos para dar lugar a la Madrastra. En

escala de gradación, en tono irónico. 
"Barojiana”, el relato del servicio militar ordinario, deja en claro, esta inversión de la madre, en palabras de un sargento: “A qué cuando veis un francés os da rabia? ¿Sí? Pues, 'eso' es la Patria” (BENET, 1987, p.18)

Es por eso quizá que los espacios se definen por la ruptura de la guerra civil cuyo exterior es amenazante mientras que los espacios de lo interno, en esa lucha cuerpo a cuerpo, intentan transgredir para recuperar esa memoria invicta, aunque no siempre lo logre. Lo externo, en tanto público se rige por el carácter amenazante del Estado censor, mientras que lo interno, como espacio íntimo, permite muchas veces la liberación de los recuerdos. Espacios característicos son, sin lugar a duda, los ambientes de las tertulias, en especial, la de Baroja.

Era todo lo contrario a un maestro y aquél que acudiera a su casa para oír de sus labios lecciones magistrales... podía salir muy defraudado. Allí no se hablaba de cosas del otro mundo ni se hacía gala de gran sabiduría y la mejor lección que se podía obtener de la tertulia era la falta de respeto hacia muchas cosas. (BENET, 1987, p.22)

La casa del gallego Díaz, donde se impartían lecciones de matemática, nos muestra este cruce exacto entre lo externo y lo interno pero, ante todo, entre el pasado y el presente :el cristal del ventanal roto por una bomba caída en tiempos de la guerra, el frío consecuente en oposición a la calefacción de la Iglesia de los jerónimos, donde Gallego se refugiaba mientras jugaba el rol de confesor para luego comentar y volver risible aquello que había escuchado pero, ante todo, la mugre y el polvo del tiempo intemporalizado, estancado. La memoria, en su metáfora perfecta, funciona en estos textos tomando el cuerpo de la ciudad prodigio, Madrid. A Madrid van los refugiados y a Madrid se le debe la cultura de la resistencia. Desde allí, la ciudad rizoma que enlaza con un hermano en el exilio de París (y, allí, la ciudad Biblioteca, la de Camus, Sartre, Malraux) y, ya con las firmas del progreso económico : la del Concordato con la Santa sede que incluirá en el Régimen a los tecnócratas del opus Dei y la de los pactos con EE.UU, el enlace con Londres, menos intelectual sin duda. Los recuerdos de San Sebastián, en Martín Santos, mediando la cultura vasca, serán otro signo de identidad de la memoria republicana, junto con su relato decisivo de cambio ideológico. En este sentido, la ciudad madrileña es también, en ese gesto de resistencia, la ciudad intertextual, la ciudad leída en Tiempo de Silencio: la pensión de Luis, con la colcha roja de raso, doña Luisa y las famosas catoblepas, serán otro signo de resaltar la importancia de estos espacios clandestinos donde se intentaba tirar abajo el régimen. El ámbito de lo cafés, herencia liberal de los artículos de Larra, y otra vez el cruce intertextual, donde un escritor en el fondo, escibía sin parar, el Café del Lyon o el del Cock, donde se discutían las nuevas corrientes. Todo ese espacio a la luz cambia por el espacio clandestino ; allí, los topoi se vuelven característicos de la restricción y el racionamiento, en palabras de Martín Gaite. Pero esa memoria que se recolecta en los intersticios de esa ciudad que ha quedado, pese a todo, que se ha mantenido en pie, prevalece en lo pùblico, invisible y uno de sus referentes está en la figura del maitre, otro personaje histórico siguiendo la tendencia barojiana:

Casi todos los maitres de Madrid habían militado en la CNT y (...), cuando ya cerrado el local,despachada la clientela y retirados los camareros, corría una última ronda y se evocaba la epopeya del puente de los franceses, el maitresituado detrás de la barra como en sus años mozos- apenas podía retener las 
lágrimas. El tiempo es vuestro. Hay que aprovechar la juventud (BENET, 1987, p.101)

Esta recuperación de pasado pone en juego un último eje, el de la ciudad palimpsesto que es, ante todo, la puesta en escena de una memoria palimpsesto que es la de la ficción como matriz de conocimiento, un conocimiento no sólo del pasado sino del presente y de una reflexión programática acerca del futuro. He aquí el gesto ideológico, la aparición del intelectual crítico y la ficción como medio que no sólo aplica sino que ofrece un análisis esencial de una memoria discursiva: "Esa memoria es y será siempre un palimpsesto y cada nueva inscripción borra la anterior, y aun cuando la última no sea- y eso es más frecuente de lo que se confiesa- más que una invención destinada a adaptar el pasado a las predilecciones del presente". (BENET, 1987, p.103)

A continuación analizaremos La construcción de la torre de Babel (BENET, 1990). Allí se despliegan las estrategias que, juntamente con las ya analizadas, nos permitirán abordar el corpus novelístico benetiano en el marco de los estudios sobre la memoria y la representación histórica.

\subsection{Memoria en palimpsesto: La construcción de la torre de Babel}

Podríamos definir palimpsesto como aquel ocultamiento que se establece en un texto al que se considera anterior, primigenio, cuyas huellas han sido borradas artificialmente. De alguna manera, se puede afirmar que todas las obras literarias traen a la memoria otras; por lo tanto, "todas las obras son hipertextuales", (GENETTE, 1989, p.19) teniendo en cuenta que cada una lo será en mayor o menor grado. A esas relaciones "librescas" es a lo que Genette llama "literatura en segundo grado", es decir, literatura fundada en otros textos.

Por ello, el término palimpsestos acude a explicar, de manera general, como un texto se superpone al otro al que no oculta del todo sino que lo deja ver por transparencia (GENETTE, 1989, p.495). Al igual que la memoria, en tanto tejido, la obra literaria, opera por capas o niveles de sentido. A la memoria le corresponden dos niveles que atraviesan la significación de los relatos que la ponen en escena: uno de referencia al pasado, que lo reformula o intenta imitar, como vimos en el relato testimonial y en el ensayo historiográfico; otro, anclado en el presente de la enunciación, que busca de esa referencia al pasado, un sentido que sea de utilidad para el presente. Para explicar la hipertextualidad, Genette propone dos tipos de derivación hipertextual: transformación e imitación. Dichas categorías no encierran conceptos antagónicos, sino grados de relación intertextual. La transformación incluye la parodia, el travestimiento y la transposición. La imitación incluye el pastiche, el charge o imitación satírica y la forgerie o imitación seria. Un caso paradigmático que nos interesa tomar en el último apartado del presente capítulo, es el de la relación analógica respecto de "La construcción de la torre de Babel”. Nos referimos, por un lado, al conjunto de cinco breves ensayos, escritos entre 1984 y $1990^{45}$, por otro, al sentido figurado de la imagen que Benet analiza. La torre de Babel es, en principio, entendida como un mito que, como fondo de un tejido, entreteje historias. Como

\footnotetext{
${ }^{45}$ Dichos ensayos fueron contribuciones orales a un curso universitario de verano sobre diversos asuntos, como el espía, la literatura medieval o la Guerra civil española. A los efectos del análisis, sólo tomaremos dos de estos ensayos. Excepto el primero, "La construcción de la torre de Babel", todos ya habían sido publicados en diversas revistas.
} 
tal, permanece como una memoria en palimpsesto de la tradición latente no explicitada en el tejido evidente. Sobre este mito, Benet, no al azar, elige la versión de Brueghel. En ella, la obra no es un elemento estático sino, por el contrario, dinámico. No le interesa mostrar el sentido acabado de la obra sino la idea de construcción a partir de dos elementos: la dialéctica sujeto-objeto (por la que la obra no se determina a si misma sino a través de los ojos del sujeto que la recrea que, en este caso, es la figura humana en su totalidad) y la reformulación del sentido bíblico (que contradice la idea de unicidad por la de la multiplicidad y diversidad de la humanidad). Estos elementos se alejan de la figuración, en el Génesis, de la "cúspide para alcanzar a Dios"y proponen en la obra una puesta telescópica marcada por la superposición de elementos arquitectónicos en oposición a la estructura helicoidal. Es esta arquitectura lo que nos interesa por cuanto la idea de construcción- que es, en definitiva, lo que pintó Brueghel-, está signada por niveles que atraviesan la temporalidad y hacen de la torre de Babel una imagen perfecta del funcionamiento de la memoria histórica. Cada nivel marca las prácticas de una memoria, que es también su hacer económico y social.

Una memoria histórica escrita con caracteres arquitectónicos que sin duda enlazaba con el "pensado hacer" del relato bíblico. [...] Las cosas ocurren de manera muy distinta con la torre telescópica, de rodelas o de tambores superpuestos. Cada tambor puede ser una repetición idéntica del anterior e inferior o puede introducir cambios. (1990, p.30)

Por eso, el momento elegido es un estado de la memoria histórica. Allí nada está completo, todo permanece en la imperfección. Quizás esa imperfección sea lo que caracteriza el elemento principal de la memoria como una construcción plagada de reconstrucciones, reemplazos y reformulaciones. El tiempo que perdura, inevitablemente, es el presente.

Babel, como toda utopía, no es tanto una réplica al proyecto divino como una expropiación del mismo, no tanto una contrarreligiòn como una preterreligión que, incómoda con la idea de relegar la oferta divina a un futuro incierto y no testimoniado, se esfuerza en actualizar en un presente que, sin duda, pasará pronto a un bien cimentado e indestructible pasado. (1990, p.38)

El rechazo de la idea de eternidad hace que la memoria sea un estado frágil que, de no ser testimoniada, especialmente en obras que logren superar al tiempo, tiende a perderse. Por eso la palabra es, para Benet, un mitema que se convierte en hilo conductor "de una experiencia que para redactar un discurso histórico tiene necesariamente que partir de una sintaxis analógica, pero nunca al revés” (BENET, 1990, p. 58). La memoria, que es lenguaje, está construida a la manera descripta por Brueghel, por tambores sucesivos que van reformulando los estadios anteriores, a la manera de un palimpsesto por el que, no obstante, pueden verse las prácticas de una generación anterior en constante construcción. Dicha construcción cobra especial importancia en la novelística benetiana, en la que nos centraremos en el siguiente capítulo. Los estados de construcción serán centrales en las novelas, en especial, en torno de la memoria de la Guerra civil española. El ensayo titulado "Tres fechas. Sobre la estrategia en la Guerra Civil española”, que retoma elementos temáticos y estilísticos de La cultura en la guerra civil y Qué fue la guerra civil, se centra en la construcción de la victoria nacionalista y la teoría que esboza será esencial en la estructuración de sus novelas, donde la 
memoria de la guerra atraviesa todos los niveles. La teoría señala que la Guerra civil se centra en las ciudades. La conquista del Estado suponía la ocupación de las grandes ciudades pero, al fracasar en su mayor parte, con excepción de Sevilla y Zaragoza, la guerra debió extenderse. Es lo que veremos en el ciclo de HL. Los principios napoleónicos, mediante los cuales se había emprendido la guerra, la Niederwerfungsstrategie según los alemanes, que se basaba en el derrocamiento directo del enemigo, ya no tenía validez frente a la resistencia de las ciudades. Por eso se rescató la Ermattungsstrategie, es decir, la estrategia que proponía no la destrucción del ejército enemigo sino el agotamiento de sus recursos económicos. La metáfora de la caída del fruto maduro proporcionada por F. Franco señala que la caída de las grandes ciudades, en especial Madrid, sería producto de dicho agotamiento. Benet lo caracteriza en tres fechas sucesivas que van desde 1936 a 1938, fecha que determinará ya la finalización de la guerra: el 23 de noviembre de 1936, en el Terminus de Leganés, cuando Franco comprendió que no estaba preparado para una guerra ni tenía planes para afrontarla, el 25 de abril de 1937, cuando Franco le confesó al general Ungría que la guerra duraría dos años más. Ese tiempo le daba cierta ventaja ya que mientras durase la guerra su jefatura de Estado recientemente estrenada no sería cuestionada así como tampoco tendría que preocuparse por la constitución del nuevo "Estado"; por último, el 1 de agosto de 1938, en el frente de Gandesa cuando, frente a la victoria, decidió optar por el camino más largo. Allí, Benet hipotetiza dos opciones:

Una de dos: o una falta total de visión estratégica, digno remate de una guerra llevada a trancas y barrancas, o un exceso de agudeza política que le permitiría adivinar los beneficios que había de derivar de una prórroga innecesaria. La historia se cierra sobre la duda y no existe el documento que la despeje. (p.115)

Esa inteligibilidad que analizamos en Qué fue la guerra civil y La cultura en la guerra civil hace que sea investigable. Incluso en la actualidad. La memoria de la guerra que persiste en palimpsesto se apoya en la memoria colectiva latente es ese el problema que ocupa la narrativa benetiana. Como señala K. Benson, en Benet es clave el planteamiento antimimético que produce una relación metafórica entre el mundo literario y la referencia histórica (tanto la experiencia traumática de la guerra como la de la etapa franquista). Por esto, es tan importante la figura de la torre de Babel como proceso de construcción diacrónico que articula los diversos estados de la memoria histórica.

\section{Conclusiones finales}

A lo largo de este trabajo hemos pretendido dar cuenta del estado de la cuestión de una filosofía de la historia después de Franco puesto que, al hablar de una filosofía de la historia narrativista debemos partir necesariamente de una filosofía de la praxis que problematice la opacidad del lenguaje y la supuesta homogeneidad del sujeto. El discurso histórico es literatura por cuanto lleva la aplicación necesaria del pasado en el hic et nunc presente y dicha aplicación está siempre bajo la mediación de la subjetividad. Ese rasgo supone un dispositivo moralizador que, en la recepción, obliga a la acción mediante la propuesta de un programa. Las esferas normativa, instrumental y estética que la modernidad había separado, en el discurso de la historia vuelven a conjugarse de manera problemática pero eficaz para comprender que los entramados textuales son reflejo, no de una realidad en sentido mimético, del pasado sino, por el contrario, una construcción figurativa para el presente, cuyo sentido literal aún no se desvela 
y sólo se comprende por su connotación. En ese presente se incorpora también el problema de la memoria.

No basta con recuperar unos huesos, con identificarlos, con tener un lugar donde honrarles y recordarles. Es preciso recuperar sus vidas, sus esperanzas en el proyecto de una España republicana abortado por la sublevación militar de 1936. La asociación quiere instar a las administraciones, a la Universidad, a los colectivos cívicos a llevar a cabo una operación multidisciplinar para que nada se pierda: los testimonios, los documentos, la geografía de aquel genocidio: fosas, arquitectura carcelaria o relacionada con ella, etc. Todos estos elementos, debidamente conservados deben servir para componer lecciones de historia, de vida y de formación en ideales de solidaridad, pacifismo y tolerancia. (Amigos de los Caídos por la Libertad-Región Murcia, 2002)

La memoria no sólo de la Guerra civil española sino también del período franquista que articula el marco teórico benetiano a partir de la intrahistoria que viene a cortar con los grandes relatos falsificados de la historia oficial. Como hemos explicado, la memoria discursiva que se despliega se corresponde con los valores republicanos de democracia y reformismo pero ambos no pueden aplicarse sin justicia. Hemos definido, siguiendo esa lógica, a la memoria colectiva como una forma de justicia y sus relatos, así como los ensayos programáticos, devienen, por consiguiente, una conquista de la ética y de la moral. Por eso, dichas narrativas están plagadas de recursos moralizadores, como la ironía, el humor y la parodia. Quizás el proyecto literario benetiano, como muchos otros integrantes de la misma generación, intente rescatar esa memoria discursiva, política y social republicana, desde una poética que no busca el realismo literal del período franquista sino, por el contrario, el realismo figurativo que sirva al presente como lugar de memoria activo, donde intervenga un narrador comprometido estética y políticamente con la memoria colectiva y la recuperación de la identidad invicta. Cabe citar, para culminar este panorama teórico-programático, a C. Martín Gaite, cuya escritura, al igual que la benetiana, se sostiene por el hilo de la memoria a la manera del hilo de Ariadna que rompe con el mal del laberinto- o su mal de archivo- para construir la tentación-moral- del bien. Por eso, explica: "El hilo de todo lo que he escrito es la memoria, el deseo de encontrar cada cual su propia coherencia de memoria y olvido: entender cada uno el sitio donde está. Eso es muy difícil. La palabra bien dicha es memoria." (MARTIN GAITE, 1999, p.3). Memoria que en la actualidad, aún sigue siendo un problema para la sociedad española, como lo demuestran las diversas columnas en diarios y revistas así como los debates parlamentarios y el descubrimiento de fosas comunes. Quizás la escritura, en un sentido positivo del pharmakon que Derrida le critica al platonismo en ese intento por deconstruir las oposiciones binarias, sirva para la cura de la memoria del mal porque la escritura no sería hipomnesis sino mneme; es decir, no una copia representativa y superficial de la memoria viva, sino la misma memoria in praesentia que ayuda a reconstruir el presente más que actualizar el pasado construido, con sus tradiciones inventadas, del franquismo. Ese imaginario es el que se intenta superar con el acto de escritura.

Así, el acto narrativo de contar como forma de superación del pasado es también una catarsis; es decir, una superación, una purificación o cura del mal, de la enfermedad del olvido porque es en sí una transformación. 


\section{Bibliografía}

AA. VV. La Guerra Civil Española, 50 años después. Barcelona: Labor, 1986.

AA. VV. La Crisis del Estado: Dictadura, República, Guerra. (1923-1939), Colección dirigida por M. TUÑON de LARA. Barcelona: Labor, 1989.

AA.VV. Juan Benet: el caballero de Región. Madrid: Insula. N 559-560, 1993.

AGAMBEN, G. Lo que queda de Auschwitz. Homo Sacer III. Valencia: Pre-textos, 1998.

AMIGOS de los Caídos por la Libertad (19391945) Región Murcia (2002). "Declaración en torno al programa en marcha para la identificación de las fosas comunes del franquismo" (URL: http:// www.fosacomun.com/DECLARACION_FOSAS_COMUNES_NOV_02.doc)

ALTHUSSER, L. Ideología y Aparatos ideológicos del Estado. México: FCE, 1970.

ANKERSMIT, F. Historical experience. California: Stanford, 2005.

ANKERSMIT, F. Historia y Tropología. Ascenso y caída de la metáfora. Buenos Aires: FCE, 1994.

ARAQUISTÁN, L. El pensamiento español contemporáneo. Buenos Aires: Losada, 1990.

ASSMAN, J. Religión y memoria cultural. Córdoba: Lilmod, 2008.

ASSMAN, J. Das kulturelle Gedächtnis: Schrift, Erinnerung und politische Identität in frühen Hochkulturen. München: C. H. Beck, 1992.

AUB, M. La gallina ciega. Madrid: EDAF, 2002.

AUB, M. Hablo como hombre. Segorbe: Biblioteca Max Aub, 2002.

AUERBACH, E. Mimesis. México: FCE, 2004.

BACHELARD, G. La poética del espacio. México: FCE, 1998.

BAJTÍN, M. Estética de la creación verbal. Buenos Aires: Siglo XXI, 1997.

BARTHES, R. Lo obvio y lo obtuso. Barcelona: Paidós, 1996.

BARTHES, R. Variaciones sobre la escritura. Buenos Aires: Paidós, 1977.

BARTHES, R. El grado cero de la escritura. Barcelona: Paidós, 1974.

BARTHES, R. El discurso de la historia. En: El susurro del lenguaje. Buenos Aires: Paidós, 1967.

BELVEDRESI, E. Consideraciones acerca de la utilidad de la Historia. Ponencia presentada en el II Congreso Internacional de Filosofía de la Historia. Reescrituras de la Memoria social. Buenos Aires, octubre de 2006.

BENET, J. Qué fue la guerra civil. Madrid: La Gaya ciencia, 1976.

BENET, J. La cultura en la guerra civil. Madrid: La Gaya ciencia, 1986.

BENET, J. La inspiración y el estilo. Barcelona: Seix Barral, 1970.

BENET, J. El ángel del señor abandona a Tobias. Barcelona: La Gaya Ciencia, 1976.

BENET, J. La moviola de Euripides. Madrid: Taurus, 1981.

BENET, J. Otoño en Madrid hacia 1950. Madrid: Visor, 1987. 
BENET, J. La construcción de la Torre de Babel. Barcelona: Siruela, 1990.

BENET, J. Londres victoriano. Barcelona: Planeta, 1989.

BENET, J. Herrumbrosas lanzas. Vol. 1. Madrid: Alfaguara, 1983.

BENET, J. Herrumbrosas lanzas. Vol. 2. Madrid: Alfaguara, 1985.

BENET, J. Herrumbrosas lanzas. Vol. 3. Madrid: Alfaguara, 1986.

BENET, J. Puerta de tierra. Valladolid: Cuatro ediciones, 2003.

BENET, J. Infidelidad del regreso. Valladolid: Cuatro ediciones, 2007.

BENSON, K. Razón y espíritu: análisis de la dualidad subyacente en el discurso narrativo de Juan Benet. Stockholm: Stockholms Universitet, 1989.

BERGSON, H. Matière et mèmoire. Paris: P.U.F., 1968.

CARR, D. Narrativa y el mundo real: un argumento para la continuidad. History and Theory, vol. XXV, n 2, 1986.

CAUDET, F. ¿De qué hablamos cuando hablamos de literatura de exilio republicano de 1939? Memoria del I Congreso Internacional de Literatura y Cultura españolas contemporáneas. Siglos XX y XXI. La Plata: Unlp, 2008.

COLliNGWOOD, R. G. Idea de la Historia. México: FCE, 2000.

COLMEIRO, J. Memoria histórica e identidad cultural. De la Postguerra a la Postmodernidad. Madrid: Anthropos, 2005.

COURTINE, J. J. Analyse du discours politique. Langages No 62, 1981.

CUESTA BUStillo, J. Memoria e historia: un estado de la cuestión. En: (ed.) Memoria e historia. Madrid: Marcial Pons, 1998.

DE LA GRANJA, J. L.; REIG TAPIA, A. (ed.). Manuel Tuñón de Lara: El compromiso con la Historia. Su vida y su obra. Bilbao: Universidad del País Vasco, 1993.

DERRIDA, J. La deconstrucción en las fronteras de la filosofía. Barcelona: Paidós, 1989.

DÍAZ PLAJA, F. La vida cotidiana en la España de la guerra civil. Madrid: Ediciones EDAF, 1994.

EAGLETON, T. Ideología. Buenos Aires: Paidós, 1997.

FONTANA, J. (ed.) España bajo el franquismo. Barcelona: Critica, 1986.

FRIEDLÄNDER, S. En torno a los límites de la representación. Buenos Aires: UNQ, 2008.

FRYE, N. Theory of Archetypal Meaning (2): Demonic Imagery. En: . Anatomy of Criticism: Four Essays. Princeton, NJ: Princeton UP, 1973.

GARCÍA BERRIO, A. Teoría del discurso y Estética de la representación, Valencia: Consorci de Museus de la Generalitat, 1998.

GENNETTE, G. Palimpsestos. Madrid: Taurus, 1989.

GINZBURG, C. El queso y los gusanos. Madrid: Síntesis, 1998.

GOYTISOLO, J. Memoria, olvido, amnesia y memoricidio. En: . Cogitus interruptus.

Barcelona: Seix Barral, 1999. 
GRACIA GARCÍA, J.; RUIZ CARNICER, M. A. La España de Franco (1939-1975). Madrid: Síntesis, 2000.

GUARIGLIA, O. Ideología, Verdad y Legitimación. Buenos Aires: FCE, 1993.

GRASS, G. Artículos y ensayos, Barcelona: Círculo de Lectores, 1999.

HALBWACHS, M. Les Cadres Sociaux de la Mémoire. Paris: Albin Michel, 1997.

HALBWACHS, M. La Mémoire collective, Paris: P.U.F., 1950.

HEGEL, F. Lecciones sobre la Filosofía de la Historia Universal. Madrid: Alianza, 2004.

HERZBERGER, D. The novelistic World of Juan Benet. Clear Creek: The American Hispanist, 1976.

HOBSBAWM, E. Inventando tradiciones. El discurso histórico. Barcelona: Crítica, 1983.

HUTTON, P. History as an art of memory. Hanover, N.H: University Press of New England, 1993.

ILIE, P. Literatura y exilio interior. Madrid: Fundamentos, 1980.

KELLNER, H. Language and History representation. Madison: The University of Wisconsin press, 1989.

KOSELlECK, R. Futuro pasado. Para una semántica de los tiempos históricos. Barcelona: Paidós, 1979.

KRISTEVA, J. Poderes de la Perversión. Buenos Aires: Siglo XXI, 1988.

LABANYI, J. History and Hauntology; or What does one do with with the ghosts of the past? Reflections on spanish film and fiction of the Post Franco period. En: RESINA, J. R. (ed.). Disremembering the Dictatorship: the politics of memory in the spanish transition to Democracy. Amsterdam: Rodopi, 2000.

LAKOFF, G.; JOHNSON, M. Metáforas de la vida cotidiana. Madrid: Cátedra, 1995.

LAKOFF, G.; TURNER, M. More than cool reason. London: The University of Chicago Press. Trad. de L. Eisner, 1989.

LEVI, P. Si esto es un hombre. Barcelona: Muchnik, 1986.

LEVI, P. Los hundidos y los salvados. Barcelona: Muchnik Editores, 1997.

LONGHURST, C. Historia y Ficción: concepto barojiano de la novela histórica. En: Las novelas históricas de Pio Baroja. Madrid: Guadarrama, 1974.

LOTMAN, I. La semiósfera. Madrid: Cátedra, 1979.

MARGALIT, A. Ética del recuerdo. Lecciones Max Horkheimer. Barcelona: Herder, 2002.

MARTÍN GAITE, C. Dos textos inéditos [epílogo a la edición de La inspiración y el estilo. Madrid: Alfaguara. Págs. 225-269, 1999.

NORA, P. Les lieux de mémoire. Paris: Gallimard, 1997.

NORA, P. Entre Mèmoire et Histoire. La problèmatique de lieux. En: Lieux de mèmoire. Paris: Gallimard, 1984.

PRESTON, P. (ed.). España en crisis. Evolución y decadencia del régimen de Franco. México: FCE, 
1978.

REIG TAPIA, A. Memoria de la Guerra Civil. Los mitos de la tribu. Madrid: Alianza, 1999.

RICOEUR, P. La memoria, la historia, el olvido. México: FC.E, 2000.

RICOEUR, P. Tiempo y Narración. Madrid: Cristiandad, 1985.

RICOEUR, P. La lectura del tiempo pasado: memoria y olvido. Madrid: Arrecife, 1999.

ROBIN, R. Los manuales de Historia de la III República francesa: un problema de hegemonía ideológica. En: MONTEFORTE TOLEDO, M. El discurso político. México: Nueva imagen, 1980.

ROBIN, R. Identidad, memoria y relato. La imposible narración de sí mismo. Buenos Aires: Of. de Publicaciones del CBC, 1996.

RUNIA, E. Burying the dead, creating the past. Ponencia presentada en el II Congreso Internacional de Filosofía de la Historia. Reescrituras de la Memoria social. Buenos Aires, octubre de 2006.

SEMPRÚN, J. La escritura o la vida. Madrid: Cátedra, 1998.

SILVA, E. Las tareas pendientes. El País. 15 de diciembre, 2002.

SOLDEVILA DURANTE, I. La novela española desde 1936, Madrid: Alhambra, 1982.

TRAVERSO, E. El pasado, instrucciones de uso. Historia, memoria, política. Madrid: Marcial Pons, 2000.

TODOROV, T. Los abusos de la memoria. Barcelona: Paidós, 2000.

VALDÉS, M. J. Teoría de la hermenéutica fenomenológica. En: Graciela Reyes (ed.). Teorías literarias en la actualidad. Madrid: El arquero, 1989.

TUSELL, J. Alfonso XIII, un centenario polémico. El País. 5 de junio, 2002.

VERNON, K. M. El lenguaje de la memoria en la narrativa española contemporánea. En: Neumeister-Sebastián (ed.). HECKELMANN-DIETER (introd.); MERGALLI-FRANCO (introd.), Actas del IX Congreso de la Asociación Internacional de Hispanistas, I \& II, Frankfurt: Vervuert, 1989.

VÁZQUEZ MONTALBÁN, M. La literatura en la construcción de la ciudad democrática. Madrid: Crítica, 1998.

VÁZQUEZ MONTALBÁN, M. Crónica sentimental de España. Barcelona: Destino, 1986.

VERNANT, J. P. Historia de la memoria y memoria histórica. En: ¿Por qué recordar? Madrid: Granica, 1998.

VICO, G. Principios de una ciencia nueva en torno a la naturaleza común de las naciones. México: FCE, 1978 .

VIRNO, P. El recuerdo del presente. Ensayo sobre el tiempo histórico. Buenos Aires: Paidós, 2003.

WEINRICH, H. Estructura y función de los tiempos en el lenguaje. Madrid: Gredos, 1978.

WHITE, H. El contenido de la forma. Narrativa, discurso y representación histórica. U.P: J. Hopkins, 1987.

WHITE, H. Teoría literaria y escrito histórico. En: El texto histórico como artefacto literario. Buenos Aires: Paidós, 1978. 
WINTER, U. (ed.) Lugares de la memoria de la Guerra civil y el Franquismo. Representaciones literarias y visuales. Madrid: Iberoamericana, 2006.

ZIZEK, S. Ideologia: un mapa de la cuestión. Buenos Aires: FCE, 2003.

Recebido em: 17/05/2020

Aceito em: 28/06/2020 